\title{
Phosphorus sources for phosphatic Cambrian carbonates
}

\section{Citation}

Creveling, J. R., D. T. Johnston, S. W. Poulton, B. Kotrc, C. Marz, D. P. Schrag, and A. H. Knoll. 2013. "Phosphorus Sources for Phosphatic Cambrian Carbonates." Geological Society of America Bulletin 126 (1-2) (December 6): 145-163. doi:10.1130/b30819.1.

\section{Published Version}

doi:10.1130/B30819.1

\section{Permanent link}

http://nrs.harvard.edu/urn-3:HUL.InstRepos:16422963

\section{Terms of Use}

This article was downloaded from Harvard University's DASH repository, and is made available under the terms and conditions applicable to Open Access Policy Articles, as set forth at http:// nrs.harvard.edu/urn-3:HUL.InstRepos:dash.current.terms-of-use\#OAP

\section{Share Your Story}

The Harvard community has made this article openly available.

Please share how this access benefits you. Submit a story.

Accessibility 
$1 \quad$ P sources for phosphatic Cambrian carbonates

2 Jessica R. Creveling $^{1^{*}}$, David T. Johnston ${ }^{1 \dagger}$, Simon W. Poulton ${ }^{2}$, Benjamin Kotrc ${ }^{1}$,

3 Christian März ${ }^{3}$, Daniel P. Schrag ${ }^{1}$, Andrew H. Knoll ${ }^{1,4}$

$4{ }^{1}$ Department of Earth and Planetary Sciences, Harvard University, 20 Oxford Street,

5 Cambridge, MA 02138, USA

$6 \quad{ }^{2}$ School of Earth and Environment, University of Leeds, Leeds, LS2 9JT, UK

$7 \quad{ }^{3}$ School of Civil Engineering and Geosciences, Newcastle University, Drummond

8 Building, Newcastle upon Tyne, NE1 7RU, UK

$9{ }^{4}$ Department of Organismic and Evolutionary Biology, Harvard University, 26 Oxford

10 Street, Cambridge, MA 02138, USA

$11 \quad$ *Email: jcrevel@gps.caltech.edu

$12 †$ Email: johnston@eps.harvard.edu

\section{ABSTRACT}

15 The fossilization of organic remains and shell material by calcium phosphate 16 minerals provides an illuminating, but time-bounded, window into Ediacaran-

17 Cambrian animal evolution. For reasons that remain unknown, phosphatic fossil

18 preservation declined significantly through Cambrian Series 2. Here we investigate

19 the phosphorus (P) sources for phosphatic Cambrian carbonates, presenting

20 sedimentological, petrographic, and geochemical data from the Cambrian Series 2-

213 Thorntonia Limestone, Australia, some of the youngest Cambrian strata to display

22 exceptional phosphatic preservation of small shelly fossils. We find that within

23 Thorntonia sediments, phosphate was remobilized by organic decay and bacterial

24 iron reduction, with subsequent reprecipitation largely as apatite within the

25 interiors of small shelly fossils. We discuss the merits of bioclastic-derived, organic

26 matter-bound, or iron-bound $\mathbf{P}$ as potential sources to these strata. Petrographic

27 observations suggest that the dissolution of phosphatic skeletal material did not

28 source $\mathbf{P}$ for fossil preservation. In contrast, high organic carbon contents imply

29 significant organic fluxes of $P$ to Thorntonia sediments. Sedimentology and iron-

30 speciation data indicate that phosphorus enrichment occurred during times of

31 expanded anoxic, ferruginous conditions in subsurface water masses, suggesting

32 that phosphorus adsorption to iron minerals precipitating from the water column

33 provided a second significant $P$ source to Thorntonia sediments. Simple 
34 stoichiometric models suggest that by themselves neither organic carbon burial nor

35 an iron shuttle can account for the observed phosphorus enrichment. Thus, we infer

36 that both processes were necessary for the observed phosphorus enrichment and

37 subsequent fossil preservation in the Thorntonia Limestone.

\section{INTRODUCTION}

40 Phosphorite and phosphatic carbonate define a spectrum of sedimentary lithologies

41 enriched in the authigenic calcium phosphate mineral apatite (Kazakov, 1937; Baturin

42 and Bezrukov, 1979; Riggs, 1986; Cook and Shergold, 1986; Cook et al., 1990; Föllmi,

43 1996; Trappe, 2001). The punctuated temporal distribution (Cook and McElhinny, 1979;

44 Cook and Shergold, 1984, 1986) and evolving spatial distribution (Brasier and Callow,

45 2007) of phosphatic lithologies through Earth history suggest that unique and restrictive

46 physical (Filippelli and Delaney, 1992) and/or chemical (e.g., Föllmi, 1996) conditions

47 govern phosphate deposition in time and space.

48 There are many reasons to want to understand this distribution. Perhaps foremost

49 is the practical concern for understanding how ore-grade sedimentary phosphorites form

50 (e.g., Cook and Shergold, 1986). As with petroleum, phosphate ores are approaching

51 peak production, while global demand continues to rise (Cordell et al., 2009; Filippelli,

52 2011). At the same time, biogeochemists increasingly invoke perturbations to the ancient

53 phosphorus cycle to explain inferred fluctuations in biological productivity, organic

54 carbon burial and oxidant accumulation over geological time-scales (Tyrrell, 1999;

55 Bjerrum and Canfield, 2002; Saltzman, 2005; Holland et al., 2006; Konhauser et al.,

56 2007; Algeo and Ingall, 2007; Planavsky et al., 2010; Swanson-Hysell et al., 2012).

57 Finally, phosphatic deposits provide a direct window into evolutionary history through 
58 the exceptional preservation of fossils (Cook, 1992; Bengtson and Zhao, 1997; Xiao and

59 Knoll, 2000; Butterfield, 2003; Porter, 2004a).

60 A global phosphogenic window coincides with major evolutionary innovation

61 during the Ediacaran and Cambrian periods (Cook and Shergold, 1984; 1986; Cook,

62 1992). Much of our knowledge of early animal diversification derives from

63 biomineralized and soft-bodied metazoans replaced and/or templated by phosphate

64 minerals (Bengtson et al., 1990; Xiao and Knoll, 1999; 2000; Donoghue et al., 2006;

65 Dornbos et al., 2006; Kouchinsky et al., 2012). Phosphatization taphonomy is tied to the

66 biogeochemical cycle of phosphorus and, for reasons that remain unknown, a major

67 decline in the incidence of phosphatic lithologies and phosphatic fossil preservation

68 occurs during Cambrian Series 2 (Cook and McElhinny, 1979; Porter, 2004b; Donoghue

69 et al., 2006). To understand the loss of phosphatic lithologies, and the consequent closure

70 of the Cambrian phosphatization taphonomic window, we must first understand how

71 phosphorus entered the sediment column and how it was subsequently redistributed and

72 concentrated around skeletal elements. In this paper, we ask specifically: what was the

73 source of phosphorus to phosphatic carbonates characterized by exceptional skeletal

74 preservation?

75 Geochemistry provides one avenue to address this question. A common view

76 holds that enhanced delivery of reactive phosphorus (i.e., phosphorus that may undergo

77 biogeochemical transformations within the sediment column) to the sea floor is the

78 primary variable governing the development of phosphatic lithologies (e.g., see Föllmi,

79 1996, and references therein; Papineau, 2010). In modern marine environments, the

80 delivery of reactive phosphorus to the sea floor occurs predominantly in association with 
81 two phases (e.g., Delaney, 1998; Benitez-Nelson, 2000): phosphorus bound within

82 organic matter (Redfield, 1958) and/or phosphorus adsorbed to/co-precipitated with

83 particulate iron minerals (herein referred to as the 'Fe-P shuttle') (Berner, 1973; Shaffer,

84 1986; Feely et al., 1991; Feely et al., 1998; Poulton and Canfield, 2006). To examine the

85 extent to which these reactive phosphorus sources contributed to ancient phosphatic

86 deposits, we report high-resolution phosphorus and iron speciation data, stable carbon

87 isotope measurements, and trace element concentrations for the phosphatic Thorntonia

88 Limestone, Georgina Basin, Australia (Cambrian Series 2-3; Southgate, 1988; Southgate

89 and Shergold, 1991), and, for comparison, the overlying non-phosphatic Arthur Creek

90 Formation. We explore the possibility that bioclastic-bound, organic-bound, and iron-

91 bound $\mathrm{P}$ sourced the Thorntonia phosphatic carbonates and develop simple mathematical

92 models to assess the relative importance of organic- and iron-bound P. We find that while

93 the high organic carbon content of the Thorntonia Limestone suggests that organic-bound

$94 \mathrm{P}$ contributed significantly to authigenic apatite formation, $\mathrm{C}$ to $\mathrm{P}$ ratios indicate that

95 organic-bound $\mathrm{P}$ was insufficient to account entirely for the observed phosphorus

96 enrichment. Sedimentology and iron speciation data indicate that these formations

97 accumulated under anoxic, ferruginous subsurface water masses, allowing for the

98 possibility that $\mathrm{P}$ adsorbed to iron minerals precipitating from the water column

99 augmented organic-bound P delivery to the sediment column. Nonetheless, simple

100 mathematical models indicate that, by itself, iron-bound phosphorus delivery is also

101 incapable of accounting for the observed phosphorus enrichment. Thus, we infer that both

102 organic-bound and iron-bound phosphorus sources were necessary for the development

103 of the fossil-bearing phosphatic carbonates of the Thorntonia Limestone. 


\section{GEOLOGIC BACKGROUND}

106 The Centralian Superbasin is a laterally extensive intracratonic basin that initiated during

107 Neoproterozoic transcontinental rifting of Rodinia. Regional tectonic events subsequently

108 dissected the superbasin into a mosaic of discrete, asymmetric, polyphase foreland basins

109 (Fig. 1a; Walter et al, 1995; Lindsay, 2002; Dunster et al., 2007). Here, we focus on the

110 phosphatic Cambrian strata of the southern Georgina Basin (Cook and Shergold, 1986;

111 Southgate, 1988; Southgate and Shergold, 1991), which deposited variably and

112 diachronously across the basin (Cook and Shergold, 1986; Southgate, 1988; Howard,

113 1990; Southgate and Shergold, 1991; Dunster et al., 2007).

114 The Narpa Group encompasses Cambrian Series 2 and Series 3 stratigraphy of the

115 southern Georgina Basin (Fig. 1b; Ambrose et al., 2001; Dunster et al., 2007). Deposition

116 of its lowermost member, the phosphatic Thorntonia Limestone, reflects a major

117 transgression and expansion of the Georgina Basin. For this reason, the basal contact of

118 the Thorntonia Limestone can unconformably overlie the Shadow Group, conformably

119 and gradationally overlie the Shadow Group, or overlie and re-work crystalline basement

120 (Fig. 1b). The rest of the Narpa Group records a basin-wide, shallowing-upward

121 succession that transitions from outer (lower Arthur Creek Formation), middle (upper

122 Arthur Creek Formation) and inner ramp (Steamboat Sandstone) depositional

123 environments into a flat-topped carbonate platform (Arrinthrunga Formation; Ambrose et

124 al., 2001; Dunster et al., 2007).

125 Trilobite biostratigraphy assigns Thorntonia rocks to the Ordian and early

126 Templetonian stages of Australian chronostratigraphy (Laurie, 2004a,b; Dunster et al., 
127 2007), correlative to Cambrian Series 2, Stage 4 and, possibly, lowermost Series 3, Stage

1285 (Fig. 1b; Babcock and Peng, 2007; Peng and Babcock, 2011). Trilobite biozones within

129 the Arthur Creek Formation are diagnostic for the Australian regional Ordian-

130 Boomerangian stages (Laurie, 2004a, b; Dunster et al., 2007), correlative to uppermost

131 Stage 4 of Cambrian Series 2 through to the Guzhangian Stage of Cambrian Series 3 (Fig.

132 1b; Babcock and Peng, 2007; Peng and Babcock, 2011).

\section{METHODS}

135 We examined the sedimentology and lithofacies associations of the Thorntonia and

136 Arthur Creek formations within drill core NTGS 99/1 reposited at the Northern Territory

137 Geological Survey, Alice Springs, Australia. With a water-cooled saw, we cut 534 three-

$138 \mathrm{~cm}$-long, quarter-core samples perpendicular to bedding at $\sim 10-25 \mathrm{~cm}$ resolution between

139597.58 and 347.98 meters core depth (mcd). Each sample was again divided

140 (perpendicular to bedding) into two subsamples, one half designated as a hand-sample or

141 thin-section billet, the other half pulverized with a steel ring mill. Each hand-sample

142 billet was micro-drilled along individual laminations for carbonate carbon $\left(\delta^{13} \mathrm{C}_{\mathrm{carb}}\right)$ and

143 carbonate oxygen $\left(\delta^{18} \mathrm{O}_{\text {carb }}\right)$ isotopic analysis. The evolved $\mathrm{CO}_{2}$ was measured against an

144 in-house reference gas on a VG Optima dual-inlet mass spectrometer attached to a VG

145 Isocarb preparation system. We report isotopic values in the V-PDB per mil (\%o)

146 notation. Standard reproducibility was $1 \sigma=<0.1 \%$ and $0.2 \%$ for $\delta^{13} \mathrm{C}_{\text {carb }}$ and $\delta^{18} \mathrm{O}_{\text {carb }}$,

147 respectively.

148 Sample powders were divided for carbon, phosphorus, iron, and trace element 149 geochemical analyses aimed at diagnosing the sediment- and water-column geochemistry 
150 at the time of phosphatic carbonate deposition. To determine carbon mass fractions, we

151 acidified 5-10 $\mathrm{g}$ of powdered sample with cold, $2.5 \mathrm{M}$ hydrochloric acid. The resulting

152 insoluble residue (i.e., the non-carbonate fraction, comprised predominately of

153 siliciclastics and organic matter) was isolated by filtration, rinsed thoroughly with de-

154 ionized water, then dried and weighed. The total carbonate fraction was estimated as the

155 weight percent difference between the bulk sample and the insoluble residue. To

156 determine the weight percent of total organic carbon (TOC) and its isotopic composition

$157\left(\delta^{13} \mathrm{C}_{\text {org }}\right)$, aliquots of the insoluble residue were combusted within a Carlo Erba NA 1500

158 Analyzer attached to a Thermo Scientific Delta V Advantage isotope ratio mass

159 spectrometer. Reproducibility of $\delta^{13} \mathrm{C}_{\text {org }}$ for an acetanilide standard was $0.16 \%$ ( $(1 \sigma)$. Of

160 the 100 samples processed, 29 were analyzed in duplicate and yielded an analytical

161 reproducibility of $1 \sigma=0.07$ weight percent (wt.\%) TOC. Finally, we estimated the wt. $\%$

162 of silicate phases (either clastic or authigenic) as the wt.\% of the insoluble fraction minus

163 the wt.\% of the TOC fraction.

164 The speciation of phosphorus $(\mathrm{P})$ was determined with a modified sequential

165 extraction methodology for marine sediment (Ruttenberg, 1992). Here, 150-200 mg of

166 rock powder was sequentially extracted with $10 \mathrm{~mL}$ each of (1) $0.3 \mathrm{M}$ sodium-citrate/1 M

167 sodium bicarbonate/0.14 M sodium dithionite $(\mathrm{pH}=7.5)$ for $\mathrm{P}$ bound to

168 reducible/reactive ferric iron minerals $\left(\mathrm{P}_{\mathrm{Fe}}\right),(2) 1 \mathrm{M}$ sodium acetate $(\mathrm{pH}=4.0)$ for

169 carbonate fluorapatite, biogenic hydroxyapatite, and carbonate-bound $\mathrm{P}\left(\mathrm{P}_{\text {auth+carb }}\right)$, (3) 1.2

$170 \mathrm{M}$ cold $\mathrm{HCl}$ for crystalline fluorapatite $\left(\mathrm{P}_{\mathrm{xl}}\right)$, and (4) $1.2 \mathrm{M}$ cold $\mathrm{HCl}$ after a 2 hour

171 ignition at $550^{\circ} \mathrm{C}$ for organic $\mathrm{P}\left(\mathrm{P}_{\text {org }}\right)$. To prevent $\mathrm{P}$ readsorption during the first two

172 extraction steps, two $5 \mathrm{~mL} 1 \mathrm{M} \mathrm{MgCl}_{2}$ washes were performed post-extraction. 
173 Phosphorus in extracts and wash solutions (except $\mathrm{P}_{\mathrm{Fe}}$ ) was analyzed

174 spectrophotometrically (Thermo Genesys 6) by the molybdate-blue method (Strickland

175 and Parsons, 1972; Ruttenberg, 1992); $\mathrm{P}_{\mathrm{Fe}}$ was measured by inductively coupled plasma

176 optical emission spectrometry (ICP-OES; Varian Vista-MPX). We note that Ruttenberg

177 (1992) ascribes P-speciation phase (3), $\mathrm{P}_{\mathrm{xl}}$, to detrital fluorapatite of igneous and

178 metamorphic origin. We abbreviate this phase as 'xl' for 'crystalline' so as to remove

179 reference to a genetic mechanism (i.e., detrital) for an operationally-defined phase based

180 on a chemical extraction procedure. We hypothesize about the origin of this phase in

181 greater detail in the discussion.

182 To verify the efficiency of the sequential extraction method, total $\mathrm{P}\left(\mathrm{P}_{\mathrm{T}}\right)$ values

183 were determined independently (SGS Mineral Services Group) by inductively coupled

184 plasma atomic emissions spectrometry (ICP-AES) after a standard four acid digestion

$185\left(\mathrm{HF}-\mathrm{HClO}_{4}-\mathrm{HCl}-\mathrm{HNO}_{3}\right)$. These analyses also provide the additional major and trace

186 metal concentrations reported below. To account for variable dilution by siliciclastic

187 influx, we report element concentrations normalized to aluminum (Al) in wt.\%/wt.\% and

$188 \mathrm{ppm} / \mathrm{wt}$ \% units for major and trace elements, respectively.

189 To determine the speciation of iron within our samples, we applied a modified

190 version of the sequential extraction method of Poulton and Canfield (2005). Here, 80-100

191 mg of rock powder was sequentially extracted with $10 \mathrm{~mL}$ each of (1) $1 \mathrm{M}$ sodium-

192 acetate, adjusted to $\mathrm{pH} 4.5$ with acetic acid to extract Fe associated with carbonate phases

193 such as siderite and ankerite $\left(\mathrm{Fe}_{\mathrm{carb}}\right)$; (2) $0.28 \mathrm{M}$ sodium dithionite, adjusted to $\mathrm{pH} 4.8$

194 with $0.2 \mathrm{M}$ acetic acid/0.25 M tri-sodium citrate, for iron oxides such as hematite and

195 goethite $\left(\mathrm{Fe}_{\mathrm{ox}}\right)$; and (3) $0.2 \mathrm{M}$ ammonium oxalate/0.17 $\mathrm{M}$ oxalic acid for magnetite 
$196\left(\mathrm{Fe}_{\mathrm{mag}}\right)$. The boiling chromium reduction distillation of Canfield et al. (1986) was used to

197 quantify sulfur (S) within pyrite from the insoluble residues derived from carbonate

198 dissolution. We used a pyrite stoichiometry $\left(\mathrm{FeS}_{2}\right)$ to relate the extracted $\mathrm{S}$ back to iron

$199\left(\mathrm{Fe}_{\mathrm{py}}\right)$. Total $\mathrm{Fe}\left(\mathrm{Fe}_{\mathrm{T}}\right)$, which comprises the sum of the diagenetically highly reactive

200 phases $\left(\mathrm{Fe}_{\mathrm{HR}}=\mathrm{Fe}_{\text {carb }}+\mathrm{Fe}_{\mathrm{ox}}+\mathrm{Fe}_{\text {mag }}+\mathrm{Fe}_{\mathrm{py}}\right)$, as well as unreactive $\mathrm{Fe}\left(\mathrm{Fe}_{\mathrm{u}}\right.$; predominately

201 silicate-bound $\mathrm{Fe}$ ), was determined via a boiling $\mathrm{HF}-\mathrm{HNO}_{3}-\mathrm{HClO}_{4}$ extraction on an

202 additional aliquot of sample powder. All iron concentrations were measured by atomic

203 absorption spectrometry (AAS). Eight replicates of one sample, 572.64 mcd, yield a RSD

204 of $2 \%, 13 \%$, and $71 \%$ for $\mathrm{Fe}_{\mathrm{carb}}, \mathrm{Fe}_{\mathrm{ox}}$, and $\mathrm{Fe}_{\mathrm{mag}}$, respectively. The high RSD of the latter

205 two phases result from measured quantities close to the instrument detection limit; that is,

206 the average wt. $\% \pm 1 \sigma$ for the eight Fe-speciation replicates is $0.110 \pm 0.002,0.016 \pm 0.002$,

207 and $0.001 \pm 0.001$ for $\mathrm{Fe}_{\mathrm{carb}}, \mathrm{Fe}_{\mathrm{ox}}$, and $\mathrm{Fe}_{\mathrm{mag}}$, respectively. At higher $\mathrm{Fe}$ concentrations for

208 each fraction, the RSD is $<5 \%$ for each stage, and this is also the case for $\mathrm{Fe}_{\mathrm{py}}$ and $\mathrm{Fe}_{\mathrm{T}}$

209 (Poulton and Canfield, 2005).

211 RESULTS

212 Lithofacies descriptions and paleoenvironmental interpretations for the Thorntonia

213 Limestone and Arthur Creek Formation from drill core NTGS 99/1

214 Markings on drill core NTGS 99/1 assign 598.4-580.1 mcd, 580.1-558.7 mcd, and

215 558.7-554.7 mcd to the informal lower, middle, and upper members, respectively, of the

216 Thorntonia Limestone (previously Hay River Formation), and 554.7-103.2 med to the

217 Arthur Creek Formation (previously Marqua Formation; Ambrose et al., 2001; Dunster et

218 al., 2007). In this study, we characterized the sedimentology and geochemistry of the 
219 entire Thorntonia Limestone and the lowermost $200 \mathrm{~m}$ of the lower Arthur Creek

220 Formation.

222 Thorntonia Limestone

223 The Shadow Group is absent from NTGS 99/1. Here, the Thorntonia Limestone directly

224 overlies Paleoproterozoic granite basement. The basal meters of the lower Thorntonia

225 member include lithic fragments and sand grains within dolomudstone, with minor cubic

226 pyrite crystals (Fig. 2a). More generally, the lower Thorntonia consists of dolomudstone

227 and peloidal dolowackestone, with pervasive structural dissolution textures creating a

228 stylolaminated to stylobedded fabric (Fig. 2b). Southgate and Shergold (1991) designated

229 the basal, arkosic, terrigenous unit as a low-stand system tract, and the overlying stylolitic

230 carbonate as a condensed transgressive / high-stand system tract.

231 Below 575.92 mcd (the lower Thorntonia Limestone) and from 580.1 - 575.92

232 mcd (the middle Thorntonia Limestone), the bulk lithology is dolostone. Stratigraphically

233 above this horizon, up to the middle-upper Thorntonia Limestone contact at $558.7 \mathrm{mcd}$,

234 the bulk lithology is limestone. Nevertheless, petrographic observation of the bulk

235 limestone lithofacies above $575.92 \mathrm{mcd}$ reveals rare euhedral dolomite rhombs within an

236 otherwise calcimudstone or calciwackestone matrix.

237 The middle Thorntonia contains four interbedded and interlaminated lithofacies

238 that occur within generally coarsening-upward meter- to sub-meter-scale packages (Fig.

239 2c). These lithofacies include: (1) black to medium gray carbonate mudstone; (2) dark to

240 medium gray peloidal, bioclastic, and, occasionally, intraclastic wackestone; (3) medium

241 to light gray peloidal and bioclastic packstone; and (4) medium to light gray bioclastic 
242 grainstone. Carbonate mudstone or wackestone lithofacies define the base of each

243 package and interlaminate or alternate gradationally on a centimeter to decimeter scale.

244 These carbonate mud-dominated lithologies typically grade upward into, and contact

245 sharply with, laminae and beds of packstone. When present, thin beds of bioclastic

246 grainstone overlie packstone beds. These grainstone beds display basal erosional contacts

247 with millimeter to half-centimeter-scale topography, and an upper contact that is either

248 sharp or erosional and overlain by beds of black to medium-gray carbonate mudstone. In

249 other cases, the upper contact is diffuse and conformable with beds of medium-gray

250 packstone or wackestone (Fig. 2d). There is a broad up-core trend: packages initiate with

251 progressively coarser lithologies and terminate with progressively thicker grainstone

252 beds. The nature of deposition of the Thorntonia Limestone within NTGS 99/1 is

253 consistent with the phosphatic lithofacies model from the northeast Georgina Basin

254 (Cycle mP of Southgate, 1988). Southgate and Shergold (1991) assign these shallowing-

255 upward cycles to the transgressive system tract.

256 We interpret the lithologic association of the middle Thorntonia to reflect

257 deposition within a subtidal to intertidal depositional environment. Mudstone,

258 wackestone, and packstone beds accumulated from suspension sedimentation in calm

259 settings that lacked significant tidal, wave, or storm activity. The coarser grain size and

260 subtle current-generated stratification observed in grainstone beds reflect a higher energy

261 depositional environment. Grainstone beds reveal no internal grading, but do show

262 evidence for amalgamation and winnowing of carbonate mud by currents or waves.

263 Deposition under the influence of waves is also manifest in rosettes of brachiopod and

264 trilobite shell fragments along basal scour surfaces of bioclastic grainstone beds (Fig. 2d). 
265 Dunster et al. (2007) interpreted the black, carbonaceous carbonates of the Thorntonia

266 Formation to represent deposition under dysoxic to anoxic conditions.

267 In NTGS 99/1, the upper Thorntonia encompasses a 4 meter-thick vuggy,

268 fossiliferous dolopackstone with laminae, beds, and pockets of bioclastic dolograinstone

269 (Fig. 2e). When present, dolospar crystals form a mosaic around bioclasts (primarily of

270 lingulate brachiopods). In addition to representing a prominent matrix constituent,

271 bioclasts occur as cumulate along dissolution seams.

272 Petrography of apatite distribution. Apatite displays three predominant modes

273 within the middle and upper Thorntonia Limestone. First, within bioclast-rich carbonate

274 lithologies, apatite occurs primarily as the internal molds (steinkerns) of conical small

275 shelly fossils or, more commonly in the upper Thorntonia Limestone, as lingulate

276 brachiopod skeletal debris (Fig. 3a). Apatite also occludes gaps between, and templates

277 the exterior of, silica-replaced skeletons (Fig. 3a). Second, in rare instances, apatite

278 occurs as cement within bioclastic grainstone lithologies (Fig. 3b), Third, within mud-

279 supported, suspension-deposited carbonate, apatite occurs as sub-angular to sub-rounded

280 coarse-silt to medium-sand-size grains, and as silt- to fine-sand-size, tabular or undulose

281 grains within well-sorted, thin beds (Fig. 3c). Due to the textural maturity and fine grain-

282 size of these lithologies, we cannot say conclusively whether these grains were eroded,

283 transported and winnowed from a site of apatite authigenesis (i.e., allochthonous apatite

284 grains) or whether they were sourced with a detrital siliciclastic influx. We favor the

285 interpretation that these grains represent re-worked authigenic grains (i.e., intraclasts of

286 authigenic cement and steinkern bioclasts) because we observe no comparable-size 
287 detrital siliciclastic grains. Below, we discuss the origin of these grains in light of 288 geochemical data.

\section{Arthur Creek Formation}

291 Within NTGS 99/1, the basal $10 \mathrm{~m}$ of the lower Arthur Creek encompasses a petroleum-

292 generating, massive black shale (Fig. 2e), or 'hot shale' (e.g., Dunster et al., 2007),

293 succeeded by planar, undulose, and corrugated interlaminae of black to dark gray organic

294 matter- and clay-rich shale and siltstone with medium to light gray calcimudstone and

295 dolomudstone. This shale also contains rare interbeds of very fine-grained bioclastic

296 packstone and grainstone (Fig. 2f). Clay- and iron-oxide-rich laminae include sub-

297 rounded to angular, very well sorted, monocrystalline quartz and authigenic pyrite

298 crystals, the latter of which often occlude pore space. Horizontal alignment of clay

299 minerals indicates that compaction enhanced the physical expression of lamination.

300 Commonly below $\sim 490 \mathrm{mcd}$, and only rarely above, decimeter-scale light gray limestone

301 nodules displace surrounding laminations and retain faint remnants of lamination,

302 indicating nodular development during compaction, but before lithification (Fig. 2g). We

303 interpret individual laminae to reflect the gravitational settling of fine particles suspended

304 by dilute turbidity currents that wafted sediment towards the basin interior, consistent

305 with an outer-ramp depositional environment (Dunster et al., 2007). The fetid,

306 carbonaceous black shale and black, carbonaceous, laminated dolostone suggest

307 deposition under dysoxic to anoxic conditions (Dunster et al., 2007).

308 In the upper meters of the measured lower Arthur Creek, a second lithofacies

309 interbeds with the laminated facies (Fig. 2h). This facies includes interbeds of light gray 
310 calcimudstone and siliciclastic siltstone. Rare truncation of undulatory laminae indicates

311 intermittent deposition under the influence of currents. This facies is a harbinger of the

312 more proximal, oxygenated ramp environment of the overlying upper Arthur Creek

313 Formation (Dunster et al., 2007), which was not measured in this study. Southgate and

314 Shergold (1991) assign the lower Arthur Creek to a transgressive system tract.

316 Geochemistry of the Thorntonia Limestone and Arthur Creek Formation

317 A generalized stratigraphic column of the Thorntonia and lower Arthur Creek is shown in

318 Figure 4a alongside chemostratigraphic variation in $\delta^{13} \mathrm{C}_{\text {carb }}$ (Fig. 4b), $\delta^{18} \mathrm{O}_{\text {carb }}$ (Fig. 4c)

319 and $\delta^{13} \mathrm{C}_{\text {org }}$ (Fig. 4d). Cross-plots of $\delta^{13} \mathrm{C}_{\text {carb }}$ and $\delta^{18} \mathrm{O}_{\text {carb }}$ display no statistically

320 significant co-variation (Fig. 4e), thereby suggesting that $\delta^{13} \mathrm{C}_{\text {carb }}$ values, at least,

321 represent the primary seawater isotopic composition. The $\delta^{13} \mathrm{C}_{\text {carb }}$ curve generated for

322 NTGS 99/1 displays two positive peaks, the first in the middle Thorntonia (563.92 mcd)

323 and the second in the Arthur Creek (506.51 mcd). Consistent with trilobite

324 biostratigraphy (Laurie, 2004a,b), we correlate the middle Thorntonia excursion to the

325 Ordian-early Templetonian isotopic event and the Arthur Creek excursion to the Late

326 Templetonian-Floran event (Fig. 4b; Lindsay et al., 2005). This assignment corroborates

327 regional isotopic variation in the southern Georgina, Amadeus, and Daly Basins (Lindsay

328 et al., 2005) and, further afield, to the Argentine Precordillera (Gomez et al., 2007), the

329 Great Basin, U.S.A. (Saltzman, 2005), South China (Zhu et al., 2004; Guo et al., 2010),

330 and northwest China (Wang et al., 2011).

331 Small magnitude discontinuities in $\delta^{13} \mathrm{C}_{\text {carb }}$ chemostratigraphy occur across the

332 informal member boundaries of the Thorntonia Limestone (Fig. 4b). These 
333 discontinuities likely represent erosive events or hiatuses in deposition. In support of the

334 former interpretation, an increase in $\mathrm{Zr} / \mathrm{Al}$ occurs across the middle/upper Thorntonia

335 contact (Supplementary Figure 1). Elevated $\mathrm{Zr} / \mathrm{Al}$ ratios define erosional surfaces where

336 high-energy currents winnow fine-grained, low-density siliciclastics (characterized by

$337 \mathrm{Al}$ ) and concentrate high-density minerals (characterized by Zr; Vine and Tourtelot,

338 1970). Unlike carbon isotopes, secondary fluid migration does not affect the $\mathrm{Zr} / \mathrm{Al}$ ratio.

339 Thus, this proxy confirms sediment winnowing during deposition of the upper

340 Thorntonia. Regionally, the Thorntonia Limestone-Arthur Creek Formation contact

341 represents a sequence boundary, with karstification developed along this surface in the

342 western margin of the basin (Dunster et al., 2007). While the formation boundary within

343 NTGS 99/1 represents a sharp lithologic break, $\delta^{13} \mathrm{C}_{\text {carb }}$ values display general continuity

344 across this boundary (Fig. 4b), suggesting either relative temporal continuity or fortuitous

345 resumption of deposition with similar carbon isotopic composition. Isopach maps of the

346 Arthur Creek show that the formation thickens to the east-southeast, where the NTGS

347 99/1 drill core intercepted the maximum depocenter of the preserved basin margin

348 (Dunster et al., 2007). Thus, under the former scenario, the Thorntonia Limestone-

349 Arthur Creek Formation boundary within NTGS 99/1 could represent a correlative

350 conformity of the regional sequence boundary, with limited time missing across this

351 lithologic contact.

352 Within NTGS 99/1, $\delta^{13} \mathrm{C}_{\text {org }}$ displays co-variation with $\delta^{13} \mathrm{C}_{\text {carb }}$ within the lower

353 Thorntonia Limestone and no co-variation with $\delta^{13} \mathrm{C}_{\text {carb }}$ within either the middle/upper

354 Thorntonia or the Arthur Creek formations (Fig. 4d,f; lower Thorntonia: $\mathrm{R}^{2}=0.75$;

355 middle/upper Thorntonia: $\mathrm{R}^{2}=0.04$; Arthur Creek: $\mathrm{R}^{2}=0.2$ ). TOC varies from 0.1-2.9 
356 wt.\% in the Thorntonia, displaying a generally increasing trend in the lower Thorntonia

357 and high variance in the middle Thorntonia. TOC ranges from 0.1 to $2.5 \mathrm{wt} . \%$ in the

358 lower Arthur Creek, with higher values at the base of the formation, decreasing towards a

359 mean of $0.1 \mathrm{wt} . \%$ TOC in the upper $100 \mathrm{~m}$ of the measured core interval (Fig. 4d).

360 Despite the lack of covariance between $\delta^{13} \mathrm{C}_{\text {carb }}$ and $\delta{ }^{13} \mathrm{C}_{\text {org }}$ in strata of the middle/upper

361 Thorntonia and the Arthur Creek Formation, one trend emerges: high (> $1.0 \mathrm{wt} . \%$,

362 medium $(0.2<$ wt.\% < 1.0), and low $(<0.2$ wt. \%) TOC correlate with light,

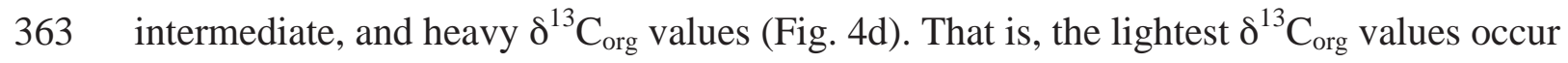

364 in the most organic- and phosphorus-rich lithofacies, the middle Thorntonia Limestone

365 (cf., Bartley et al., 1998, and Guo et al., 2013). The latter two TOC bins generally

366 correspond to samples from the Arthur Creek below and above 430 mcd, respectively,

367 which is the transition between the laminated facies and the interbedded carbonate

368 mudstone-siliciclastic shale and siltstone facies.

369 Total phosphorus $\left(\mathrm{P}_{\mathrm{T}}\right)$ within the Thorntonia Limestone ranges up to 3.9 wt.\%

370 (Fig. 5a). $\mathrm{P}_{\mathrm{T}}$ increases systematically within the lower Thorntonia and the lowermost

371 middle Thorntonia, followed by an additional increase around $575 \mathrm{mcd}$. We note that the

372 transition from dolostone (stratigraphically below $575.92 \mathrm{mcd}$ ) to limestone

373 (stratigraphically above $575.92 \mathrm{mcd}$ ) within drill core NTGS 99/1 occurs just below this

374 jump in P content (Figs 5a,b). The overlying meters of the middle and upper Thorntonia

375 display high variance in $\mathrm{P}_{\mathrm{T}}$. In contrast, the maximum value of $\mathrm{P}_{\mathrm{T}}$ within the Arthur

376 Creek is 0.4 wt. $\%$, but is typically much lower with a median of $0.03 \mathrm{wt} . \%$ and $1^{\text {st }}$ and $3^{\text {rd }}$

377 quartile values of 0.02 and 0.04 wt.\%, respectively (Fig. 5a). 
We tested the fidelity of the P sequential extraction method by comparing the sum

379 of the operationally-defined pools $\left(\mathrm{P}_{\mathrm{T}}=\mathrm{P}_{\mathrm{xl}}+\mathrm{P}_{\text {auth+carb }}+\mathrm{P}_{\mathrm{org}}+\mathrm{P}_{\mathrm{Fe}}\right)$ to the total

380 phosphorus content determined by ICP-AES analysis. The consistency between these two

381 measurement techniques (slope of linear regression $=1.1, \mathrm{R}^{2}=0.88$; Fig. 5e) increases

382 confidence in the values of the constituent sequential extraction phases. In both the

383 Thorntonia Limestone and the Arthur Creek Formation, the operationally-defined $\mathrm{P}_{\mathrm{xl}}$ and

$384 \mathrm{P}_{\text {auth+carb }}$ phases dominate $\mathrm{P}_{\mathrm{T}}$, while $\mathrm{P}_{\text {org }}$ and $\mathrm{P}_{\mathrm{Fe}}$ contribute a negligible fraction (Fig. 5b).

385 The median $\left(1^{\text {st }}, 3^{\text {rd }}\right.$ quartile $)$ percent contribution to $\mathrm{P}_{\mathrm{T}}$ are: $\mathrm{P}_{\mathrm{xl}}=91.5 \%(77.5,94.4)$,

$386 \mathrm{P}_{\text {auth }+ \text { carb }}=7.5 \%(3.7,19.5)$, and $\mathrm{P}_{\text {org }}=0.4 \%(0.2,1.5) . \mathrm{P}_{\mathrm{Fe}}$ was measured only on a subset

387 of samples, but this phase contributes minimally to $\mathrm{P}_{\mathrm{T}}$ (a median of $0.1 \%$ with $1^{\text {st }}$ and $3^{\text {rd }}$

388 quartiles of 0.0 and $0.4 \%$, respectively).

389 Total iron $\left(\mathrm{Fe}_{\mathrm{T}}\right)$ varies from $0.06-1.49 \mathrm{wt} . \%$ in the Thorntonia Limestone and

390 from 0.32-2.71 wt.\% in the Arthur Creek Formation (Fig. 5c). In general, $\mathrm{Fe}_{\mathrm{T}}$ is lowest

391 where $\mathrm{P}_{\mathrm{T}}$ is highest. Based on the slope of linear regression, 88\% of $\mathrm{Fe}_{\mathrm{T}}$ resides in $\mathrm{Fe}_{\mathrm{HR}}$

392 phases within the Thorntonia $\left(\mathrm{R}^{2}=0.92\right.$; Fig. 6a). In contrast, within the Arthur Creek,

$393 \sim 48 \%$ of $\mathrm{Fe}_{\mathrm{T}}$ resides in $\mathrm{Fe}_{\mathrm{HR}}\left(\mathrm{R}^{2}=0.57\right.$; Fig. 6a), consistent with the higher siliciclastic

394 fraction for these lithologies. The lower coefficient of determination for the Arthur Creek

395 Formation reflects a decrease in $\mathrm{Fe}_{\mathrm{HR}} / \mathrm{Fe}_{\mathrm{T}}$ from 0.66 at the base of the formation to $\sim 0.3$

396 near the top of the measured core interval. Reduced iron phases, $\mathrm{Fe}_{\mathrm{py}}$ and $\mathrm{Fe}_{\text {carb }}$, dominate

$397 \mathrm{Fe}_{\mathrm{HR}}$ in both formations, while oxidized and partially oxidized iron phases, $\mathrm{Fe}_{\mathrm{ox}}$ and

$398 \mathrm{Fe}_{\mathrm{mag}}$, contribute a minimal fraction (Fig. 5c). Based on the slope of the linear regression,

$39982 \%$ of $\mathrm{Fe}_{\mathrm{HR}}$ resides as $\mathrm{Fe}_{\text {carb }}$ within the lower Thorntonia $\left(\mathrm{R}^{2}=0.62\right.$; Fig. 6c) while $\mathrm{Fe}_{\mathrm{py}}$

400 accounts for only a minor contribution that has no statistically significant correlation with 
$401 \mathrm{Fe}_{\mathrm{HR}}$ (Fig. 6b). As such, the gradual decrease in $\mathrm{Fe}_{\mathrm{HR}}$ within the lower Thorntonia reflects

402 a systematic decrease in $\mathrm{Fe}_{\text {carb }}$ from very high values of $1.3 \mathrm{wt} . \%$, to $\sim 0.3 \mathrm{wt} . \%$. In the

403 middle and upper Thorntonia, $64 \%$ of $\mathrm{Fe}_{\mathrm{HR}}$ resides as $\mathrm{Fe}_{\mathrm{py}}\left(\mathrm{R}^{2}=0.95\right.$; Fig. 6b) and $31 \%$

404 resides as $\mathrm{Fe}_{\text {carb }}\left(\mathrm{R}^{2}=0.82\right.$; Fig. 6c). For the lower Arthur Creek, $73 \%$ and $26 \%$ of $\mathrm{Fe}_{\mathrm{HR}}$

405 reside in $\mathrm{Fe}_{\mathrm{py}}\left(\mathrm{R}^{2}=0.94\right.$; Fig. 6b) and $\mathrm{Fe}_{\text {carb }}\left(\mathrm{R}^{2}=0.72\right.$; Fig. 6c), respectively.

406 When we parse the Fe-speciation data of the middle Thorntonia Limestone

407 samples by lithology, we see a similar partitioning of Fe phases as when we group all

408 samples within members (as presented above). Within the dolostone of the middle

409 Thorntonia (580.1 - 575.92 mcd), $98 \%$ of $\mathrm{Fe}_{\mathrm{T}}$ resides in $\mathrm{Fe}_{\mathrm{HR}}\left(\mathrm{R}^{2}=0.99\right)$; in contrast,

410 within the limestone of the middle Thorntonia (575.92 mcd $-558.7 \mathrm{mcd}$ ), 89\% of $\mathrm{Fe}_{\mathrm{T}}$

411 resides in $\mathrm{Fe}_{\mathrm{HR}}\left(\mathrm{R}^{2}=0.95\right)$. Likewise, within middle Thorntonia dolostone, $67 \%\left(\mathrm{R}^{2}=\right.$

$4120.94)$ and $27 \%\left(\mathrm{R}^{2}=0.69\right)$ of $\mathrm{Fe}_{\mathrm{HR}}$ resides in $\mathrm{Fe}_{\mathrm{py}}$ and $\mathrm{Fe}_{\text {carb }}$, respectively; within the

413 middle Thorntonia limestone, $68 \%\left(\mathrm{R}^{2}=0.96\right)$ and $30 \%\left(\mathrm{R}^{2}=0.86\right)$ of $\mathrm{Fe}_{\mathrm{HR}}$ resides in

$414 \mathrm{Fe}_{\mathrm{py}}$ and $\mathrm{Fe}_{\mathrm{carb}}$, respectively.

415 Within NTGS 99/1, the median $\left(1^{\text {st }}, 3^{\text {rd }}\right.$ quartile $)$ percent acid insoluble fraction

416 (i.e., silicates) within the Thorntonia is $8.3 \%(5.3,17.0)$ as compared to $44.0 \%$ (32.8,

417 54.3) for the Arthur Creek (Supplementary Figure 1). TOC/Al ratios are higher and more

418 variable in the Thorntonia than for the Arthur Creek (Supplementary Figure 1). Fe/Al

419 ratios and $\mathrm{Mn} / \mathrm{Al}$ ratios decline throughout the lower Thorntonia (save for a couple of

420 high values in the upper Thorntonia; Supplementary Figure 1). The detrital-associated

421 trace element ratio $\mathrm{Zr} / \mathrm{Al}$ is low and variable within the Thorntonia compared to the

422 Arthur Creek Formation and displays an abrupt increase across the middle/upper

423 Thorntonia boundary. (See Supplementary Information for a discussion of aluminum- 
424 normalized concentrations of redox-sensitive and bioessential trace metals;

425 Supplementary Figure 2.)

426

\section{DISCUSSION}

428 How do these geochemical data inform our understanding of the source of phosphorus to

429 phosphatic Thorntonia carbonates and, more broadly, the loss of phosphatic lithologies

430 and consequent closure of the phosphatization taphonomic mode during Cambrian Series

4312 ? To address these questions, we combine petrographic observations with P-speciation

432 data to quantify authigenic apatite within the Thorntonia Limestone. In turn, we explore

433 the possibility that $\mathrm{P}$ bound within bioclasts, organic matter, or iron minerals sourced the

434 observed $\mathrm{P}$ within these lithologies. Finally, we present a mathematical framework for

435 which to deconvolve the relative contribution of the two most likely sources-P bound

436 with organic matter or iron minerals - to authigenic apatite nucleation.

438 Source(s) of phosphorus to the Thorntonia Limestone and Arthur Creek Formation

439 How much of the apatite within the Thorntonia Limestone and Arthur Creek Formation

440 must we account for with P delivery shuttles? Phosphorus speciation provides a

441 (semi)quantitative measure of the partitioning of phosphorus within a sedimentary

442 succession. The majority of P extracted from NTGS 99/1 is operationally classified as

443 fluorapatite of detrital igneous and/or metamorphic origin ( $\mathrm{P}_{\mathrm{xl}}$; Ruttenberg, 1992) and

444 constitutes a median $\left(1^{\text {st }}, 3^{\text {rd }}\right.$ quartile $)$ of $91.5 \%(77.5,94.4)$ of $\mathrm{P}_{\mathrm{T}}$. However, we have

445 three reasons to question this genetic interpretation. First, as described above,

446 petrographic observations reveal that apatite within the Thorntonia Limestone occurs 
447 predominantly as the internal molds of small shelly fossils (Fig. 3a) or, occasionally, as

448 cement within bioclastic grainstone (Fig 3b), both indications of an authigenic origin.

449 Given the thermal history of the Georgina Basin, which reached temperatures necessary

450 to develop Type II kerogen (Dunster et al., 2007), burial diagenesis should have increased

451 the crystallinity of authigenic phosphate minerals (Shemesh, 1990). It is thus not

452 surprising that authigenic apatite formed within marine sediment during the Cambrian is

453 now operationally classified as crystalline igneous and metamorphic apatite (sensu Föllmi

454 et al., 2005). Second, within mud-supported, suspension-deposited carbonate, apatite

455 occurs as coarse-silt- to medium-sand-size grains. Given that we observe no comparable

456 size detrital siliciclastic grains, we suggest these grains are eroded, transported and

457 winnowed authigenic grains. Third, if the $\mathrm{P}_{\mathrm{xl}}$ phase comprised fluorapatite sourced to the

458 basin along with a detrital siliciclastic influx, we would predict that it should correlate

459 with the siliciclastic-associated heavy element $\mathrm{Zr} / \mathrm{Al}$ ratio. We observe no correlation

460 between $\mathrm{P}_{\mathrm{xl}}$ and $\mathrm{Zr} / \mathrm{Al}$ (Fig. 5f). Thus, consistent with petrographic observations, we

461 conclude that the $\mathrm{P}_{\mathrm{xl}}$ pool largely represents authigenic apatite and, therefore, we must

462 account for this phase with a delivery shuttle of $\mathrm{P}$ to the sediment column.

464 Bioclastic apatite as a source of phosphorus for authigenic apatite precipitation?

465 Lingulid brachiopods comprise a fraction of the bioclasts identified in samples analyzed

466 petrographically for carbonate sedimentology and apatite distribution. The presence of

467 these phosphatic bioclasts raises two issues. First, samples that contain apatite bioclasts

468 will have a wt. $\% \mathrm{P}_{\mathrm{T}}$ that overestimates the quantity of authigenic apatite. Determining the

469 actual wt.\% of $\mathrm{P}$ within authigenic apatite for these samples would require subtracting the 
470 wt.\% of bioclastic $\mathrm{P}$ from the bulk wt.\% $\mathrm{P}_{\mathrm{T}}$ determined by phosphorus speciation

471 geochemistry. One method for determining the wt.\% of P within primary phosphatic

472 bioclasts would be to use quantitative point-count data to determine the volume of

473 bioclasts, then to multiply this volume by the density of dahllite to determine the mass

474 (wt.\%) of P. Given that the percent of primary phosphatic bioclasts visually

475 (qualitatively) rarely exceeds the percent of phosphatic steinkerns and sand-sized

476 authigenic grains (see discussion above), we move forward without quantitative estimates

477 of the wt.\% of bioclastic P under the caveat that, for lingulid brachiopod-bearing

478 bioclastic lithologies, $\mathrm{P}_{\mathrm{T}}$ overestimates authigenic apatite within a sample.

479 Second, the observation of bioclasts of primary phosphatic shells raises the

480 possibility that in situ dissolution of these bioclasts may have contributed to high pore-

481 water phosphate concentration and facilitated subsequent authigenic precipitation.

482 However, petrographic observations show that inarticulate brachiopod and other

483 phosphatic skeletons are not unusually abundant in phosphate-rich Thorntonia horizons,

484 and conversely that authigenic phosphate is not unusually abundant in those samples with

485 the highest abundances of phopshatic skeletons. Nor do these remains show marked

486 evidence of dissolution. Thus, the sedimentation of phosphatic skeletal material does not

487 seem capable of sourcing the phosphate now found in Thorntonia rocks. Further, in situ

488 dissolution of phosphatic bioclasts would necessitate pore fluids that promoted the early

489 dissolution of apatite shells without concurrent dissolution of the calcium carbonate

490 shells and sediment molded and/or replaced by the precipitation of authigenic calcium

491 phosphate minerals. For these reasons, we do not invoke phosphatic skeleton-derived P as

492 a significant source for authigenic apatite precipitation. Nevertheless, if phosphatic 
493 skeleton dissolution were to have sourced $\mathrm{P}$ for authigenic apatite, then the required

494 quantity of organic and iron-bound P (discussed below) would lessen proportionately.

496 Organic-bound phosphorus as a source of phosphorus for authigenic apatite 497 precipitation?

498 Particulate organic carbon represents the main delivery shuttle of phosphorus to the 499 sediment column in the modern ocean (e.g., Delaney, 1998; Benitez-Nelson, 2000), and

500 so we ask whether organic carbon could have sourced the observed amount of $\mathrm{P}$ within

501 beds of the Thorntonia Limestone and the Arthur Creek Formation. Perhaps the simplest

502 model for organic-bound $\mathrm{P}$ delivery is to assume that organic matter arrived at the sea

503 floor with a Redfield $\mathrm{C}_{\text {org }}: \mathrm{P}_{\text {org }}$ molar ratio of $~ 106: 1$ (Redfield, 1958). However, $\mathrm{C}_{\text {org }}: \mathrm{P}_{\text {org }}$

504 of organic matter within marine sediment and, therefore, sedimentary rocks, is commonly

505 much higher than the Redfield ratio as a result of the preferential remineralization of P-

506 rich organic compounds within the water-column (Clark et al., 1998) or within the

507 sediment column (Ingall et al., 1993, Ingall and Jahnke, 1997; Van Cappellen and Ingall,

508 1996; Jilbert et al., 2011). $\mathrm{C}_{\text {org }}: \mathrm{P}_{\text {org }}$ molar ratios within the Thorntonia Limestone range

509 from 79:1 up to $17,000: 1$ [median $\left(1^{\text {st }}, 3^{\text {rd }}\right.$ quartile $\left.)=1,389: 1(521: 1,3619: 1)\right]$. Likewise,

$510 \quad \mathrm{C}_{\text {org }}: \mathrm{P}_{\text {org }}$ molar ratios within the Arthur Creek Formation range from 43:1 up to 11,770:1

$511 \quad$ median $\left(1^{\text {st }}, 3^{\text {rd }}\right.$ quartile $\left.)=903: 1(360: 1,3,372: 1)\right]$. Thus, $\mathrm{C}_{\text {org }}: \mathrm{P}_{\text {org }}$ molar ratios within

512 these lithologies deviate substantially from the Redfield ratio and, at face value, suggest

513 extensive preferential $\mathrm{P}_{\text {org }}$ loss during organic matter respiration.

514 When organic respiration occurs within the sediment column, liberated $\mathrm{P}_{\text {org }}$ may

515 'sink-switch' and precipitate as authigenic phosphate minerals (Ruttenberg and Berner, 
516 1993), as is likely the case for the development of phosphatic strata within the Thorntonia

517 Limestone. With respect to phosphorus speciation terminology, 'sink-switching' would

518 transfer $\mathrm{P}$ from the $\mathrm{P}_{\text {org }}$ phase to either the authigenic $\mathrm{P}_{\mathrm{xl}}$ or the $\mathrm{P}_{\text {auth+carb }}$ phase. In that

519 regard, $\mathrm{C}_{\text {org }}: \mathrm{P}_{\mathrm{T}}$ should provide a better estimate of the retention of organic-bound $\mathrm{P}$ to the

520 sedimentary environments of the Thorntonia Limestone and Arthur Creek Formation

521 (Ingall et al., 1993; Ruttenberg and Berner, 1993; Anderson et al., 2001; Algeo and Ingall,

522 2007). $\mathrm{C}_{\text {org }}: \mathrm{P}_{\mathrm{T}}$ ranges from 0.1-16:1 within the Thorntonia Limestone with a median ( $1^{\mathrm{st}}$,

$5233^{\text {rd }}$ quartile) value of 2.5:1 (1.2:1, 4.8:1). For the non-phosphatic Arthur Creek Formation,

$524 \mathrm{C}_{\text {org }}: \mathrm{P}_{\mathrm{T}}$ ranges from 5-157:1 with a median $\left(1^{\text {st }}, 3^{\text {rd }}\right.$ quartile) value of 17.4:1 (7.6:1,

525 44.5:1). Thus, with the exception of four samples, $\mathrm{C}_{\text {org }}: \mathrm{P}_{\mathrm{T}}$ molar ratios for both the

526 Thorntonia Limestone and the Arthur Creek Formation fall well below the canonical

527 Redfield ratio (Fig. 5d). From this perspective, both the Thorntonia Limestone and the

528 Arthur Creek Formation retain more P than would be expected based on organic matter

529 delivery with a molar $\mathrm{C}_{\text {org }}: \mathrm{P}_{\text {org }}$ ratio equal to or greater than the Redfield ratio.

530 Preferential $\mathrm{C}_{\text {org }}$ remineralization or hydrocarbon migration relative to $\mathrm{P}$ retention

531 may have resulted in a molar $\mathrm{C}: \mathrm{P}_{\mathrm{T}}$ lower than the Redfield ratio. The required $>90 \%$ loss

532 of $\mathrm{C}_{\text {org }}$ (see below) appears to be common in relatively organic-lean sediment deposited

533 on oxic Cenozoic seafloors (Anderson et al., 2001); however, given the organic carbon

534 content of Thorntonia samples, and accepting sedimentological and geochemical

535 arguments for anoxic deposition of the Thorntonia Limestone (see below), such loss

536 would have required massive remineralization under anoxic pore water conditions.

$537 \quad \delta^{13} \mathrm{C}_{\text {carb }}$ values do not show the distinctly light values that might be expected in this

538 circumstance (Schrag et al., 2013). Assuming that all phosphorus was delivered via 
539 organic matter with a Redfield ratio and was subsequently retained within the sediment

540 column, the discrepancy between the Redfield ratio and the measured $\mathrm{C}: \mathrm{P}_{\mathrm{T}}$ provides a

541 minimum estimate of $\mathrm{C}_{\text {org }}$ loss (estimated quantitatively in a later section).

542 Organic carbon loss may also occur during low-grade metamorphism (Raiswell

543 and Berner, 1987). Since the lithology of the Thorntonia Limestone precludes a confident

544 application of the suggested metrics to account for this loss (Raiswell and Berner, 1987),

545 we cannot evaluate how much this process may have contributed to the discrepancy

546 between measured $\mathrm{C}_{\text {org }}: \mathrm{P}_{\mathrm{T}}$ values and the Redfield ratio. However, we can explore

547 whether an additional phosphorus delivery shuttle augmented organic-bound P delivery

548 to the sea floor during deposition of the Thorntonia Limestone and Arthur Creek

549 Formation. We discuss this possibility in a later section.

550 Notably, phosphatic strata of the middle Thorntonia Limestone have the highest

551 measured wt. \% TOC and the lightest $\delta^{13} \mathrm{C}_{\text {org }}$ values preserved within this sedimentary

552 succession (Fig. 4c). A similar relationship has been document in Proterozoic basins and

553 attributed to differential recycling of organic matter in benthic mats (e.g., Bartley et al.,

554 1998; Guo et al., 2013). Within the Thorntonia Limestone, this relationship may result

555 from a difference in the primary isotopic composition of organic matter sourcing

556 phosphatic strata, from variable in situ remineralization of the sedimentary organic

557 carbon reservoir, or from some combination of these two processes. We do not have an

558 independent line of evidence (e.g., compound specific biomarkers) to distinguish between

559 these possibilities. Instead, we note that acceptance of either of these hypotheses to

560 explain the observed correlation between $\mathrm{P}$ content and $\delta^{13} \mathrm{C}_{\text {org }}$ values makes a prediction

561 for the mechanism of P delivery. For the case of an isotopically distinct organic carbon 
562 source to the middle Thorntonia Limestone, the C:P ratio of this source must have been

563 much lower than the canonical Redfield ratio of 106C:1P. For the case of limited $\mathrm{C}_{\text {org }}$

564 remineralization within phosphatic strata, an alternative P delivery shuttle to the sediment

565 column must have augmented organic-bound P delivery.

566

567 Iron-bound phosphorus as a source of phosphorus for authigenic apatite

568 precipitation?

569 If our estimates of organic-bound P delivery fail to account for the phosphate necessary

570 for the observed Thorntonia apatite content, what alternative source could supply this P?

571 A growing body of literature calls upon $\mathrm{P}$ adsorbed to the surface or co-precipitated with

572 metal oxides, particularly iron (oxyhydr)oxide particles, as an important shuttle of

573 phosphorus to the sea floor (Berner, 1973; Shaffer, 1986; Feely et al., 1991; Feely et al.,

574 1998; Poulton and Canfield, 2006). Additionally, under anoxic conditions, Fe(II)-

575 phosphates (e.g., vivianite, strengite) may play a more important role for marine $\mathrm{P}$

576 cycling than previously considered (e.g., März et al., 2008; Dellwig et al., 2010; Jilbert

577 and Slomp, 2013). Thus, the release of adsorbed/co-precipitated Fe-bound P to sediment

578 pore waters has previously been invoked as a necessary and significant source of $\mathrm{P}$ for

579 sedimentary apatite nucleation (Krom and Berner, 1981; Schuffert et al., 1994, 1998;

580 Slomp et al., 1996; Shen et al., 2000; März et al., 2008; Jilbert and Slomp, 2013).

581 Could the Fe-P shuttle have augmented organic-bound P delivery to Thorntonia

582 and Arthur Creek sediments? In the modern, oxygenated ocean, iron mobility is generally

583 limited to particulate fluxes of insoluble $\mathrm{Fe}^{3+}$ phases (Martin and Meybeck, 1979;

584 Poulton and Raiswell, 2002). Under these conditions, we might predict Fe-bound P 
585 delivery to these environments to be proportional to the (predominantly siliciclastic)

586 particulate $\mathrm{Fe}$ (III) flux. In contrast, under anoxic conditions the reductive dissolution of

587 iron (oxyhydr)oxides by dissimilatory iron reduction or by dissolved sulfide during early

588 diagenesis generates soluble $\mathrm{Fe}^{2+}$ that is subsequently redistributed to anoxic slope and

589 basinal environments (Canfield et al., 1996; Severmann et al., 2008; 2010; see review in

590 Lyons and Severmann, 2006). This so-called 'intrabasin iron shuttle' provides a

591 mechanism for decoupling iron delivery to the seafloor from siliciclastic sources and,

592 therefore, we hypothesize that it allows for the delivery of P adsorbed to detrital Fe(III)

593 minerals, Fe(II)-phosphate minerals (e.g., März et al., 2008; Dellwig et al., 2010; Jilbert

594 and Slomp, 2013) and P adsorbed to/co-precipitated with Fe(III)-minerals formed from

595 the oxidation of ferrous iron in the water column (cf., Mayer and Jarrell, 2000). In this

596 regard, under either an oxic or an anoxic Cambrian water-column, Thorntonia and Arthur

597 Creek sediments could have received substantial Fe-bound P; however, we note that the P

598 contribution from the Fe-bound P shuttle would have been larger if these sediments

599 accumulated under an anoxic water column.

600 The redox state of the southern Georgina Basin water column during deposition of

601 these middle Cambrian strata can be assessed using data on the speciation and enrichment

602 of sedimentary iron minerals. This geochemical method is most commonly applied to

603 fine-grain siliciclastic lithologies, where the ratios of various mineralogical phases are

604 interpreted to reflect specific and calibrated environmental redox conditions (Canfield et

605 al., 1992; Raiswell and Canfield, 1998; Raiswell et al., 2001; Poulton and Raiswell,

606 2002). On the basis of empirical evidence, $\mathrm{Fe}_{\mathrm{HR}} / \mathrm{Fe}_{\mathrm{T}}$ above 0.38 within fine-grain

607 siliciclastic lithologies indicates sediment accumulation under an anoxic water-column 
608 (Raiswell and Canfield, 1998; Raiswell et al., 2001; Poulton and Raiswell, 2002), while

$609 \mathrm{Fe}_{\mathrm{HR}} / \mathrm{Fe}_{\mathrm{T}}$ below a value of $\sim 0.22$ is suggestive of oxic conditions (Poulton and Raiswell,

610 2002; Poulton and Canfield, 2011); additionally, in the case of anoxia, $\mathrm{Fe}_{\mathrm{py}} / \mathrm{Fe}_{\mathrm{HR}}$

611 differentiates ferruginous $(<0.7-0.8)$ from euxinic $(>0.8)$ conditions (Anderson and

612 Raiswell, 2004; Poulton et al., 2004; März et al., 2008; Poulton and Canfield, 2011).

613 The Arthur Creek Formation includes a siliciclastic facies (the 'hot shale') that is

614 ideal for iron-based redox proxies (Poulton and Canfield, 2005). $\mathrm{Fe}_{\mathrm{T}}$ within the Arthur

615 Creek 'hot shale' ranges up to 2.7 wt.\% (Fig. 6a) and almost all measured highly

616 reactive iron resides in reduced iron minerals (Fig. 6b,c). $\mathrm{Fe}_{\mathrm{HR}} / \mathrm{Fe}_{\mathrm{T}}$ and $\mathrm{Fe}_{\mathrm{PY}} / \mathrm{Fe}_{\mathrm{HR}}$

617 indicate an anoxic, ferruginous redox environment during deposition of the 'hot shale'

618 (Fig. 6a,b). In contrast, strata of the interlaminated siliciclastic shale/siltstone and

619 carbonate calcimudstone facies of the Arthur Creek Formation (directly overlying the

620 'hot shale') contain a lower siliciclastic component, and this requires special attention in

621 interpreting a paleo-redox environment. We note that each iron-speciation sample

622 integrates $3 \mathrm{~cm}$ of stratigraphy; therefore, for this lithofacies, our sample preparation

623 method homogenized multiple laminae of pure siliciclastic shale/siltstone and pure

624 carbonate mudstone. Yet, despite the diluting carbonate component, $\mathrm{Fe}_{\mathrm{HR}}$ is partitioned

625 within this lithofacies in the same proportionality as the 'hot shale' (Fig. 6b,c). In this

626 regard, iron speciation data for this lithofacies of the Arthur Creek Formation are

627 consistent with the anoxic, ferruginous redox environment inferred for the underlying

628 'hot shale'.

629 Strata of the Thorntonia Limestone are composed almost entirely of carbonate, 630 and for this reason we do not to interpret these iron speciation data within the canonical, 
631 siliciclastic-derived redox framework. Instead, we emphasize that the black, organic-rich

632 carbonate strata of the middle/upper Thorntonia Limestone (Fig. 2c), biomarker and

633 organic geochemistry of the Thorntonia and Arthur Creek petroleum systems (Boreham

634 and Ambrose, 2005), and trace element data (Supplementary Information) are

635 qualitatively consistent with iron speciation metrics for the Arthur Creek Formation "hot

636 shale' (Fig. 6) for an anoxic depositional environment during accumulation of the

637 phosphatic middle/upper Thorntonia Limestone. Thus, we conclude that the Fe-oxide

638 bound P shuttle likely augmented organic-bound P delivery to the Thorntonia and Arthur

639 Creek sediment column. Further, if one accepts the sedimentological and geochemical

640 evidence for sediment accumulation under an anoxic, ferruginous water column, this then

641 allows for the possibility that $\mathrm{Fe}(\mathrm{II})$-phosphates provided a second, potentially significant

642 source of P to Thorntonia sediments.

643 Nevertheless, the limited contribution of $\mathrm{Fe}_{\mathrm{ox}}$ to $\mathrm{Fe}_{\mathrm{HR}}$ in both the Thorntonia and

644 Arthur Creek (Fig. 5c), the low $\mathrm{P}_{\mathrm{Fe}}$ values (Fig. 5b), and the present decoupling of $\mathrm{P}$

645 within the Thorntonia from $\mathrm{Fe}_{\mathrm{HR}}$ phases (Fig. 5g) all suggest that any P delivered to

646 Thorntonia sediments via the Fe-P shuttle must have been subsequently decoupled from

647 iron particles within the sediment column. One way to explain this decoupling is through

648 the reductive dissolution of Fe oxides in anoxic pore-waters. This suggestion is consistent

649 with petrological observations that require wholesale remobilization of $\mathrm{P}$ before

650 precipitation within shell interiors (Fig. 3a,b). Thus, the present distribution of $\mathrm{P}$ in the

651 Thorntonia Limestone, spatially decoupled from either iron or organic carbon sources,

652 confounds easy attribution to primary source vectors. In the following section we 
653 integrate $\mathrm{C}, \mathrm{Fe}$, and $\mathrm{P}$ geochemical data to explore the relative contribution from organic-

654 bound and iron-bound P delivery sources.

656 Assessing the relative importance of organic-bound versus iron-bound phosphorus

657 to authigenic apatite precipitation

658 To begin, we estimate whether organic matter degradation alone could provide sufficient

659 phosphorus for the observed apatite content in the Thorntonia Limestone. We then

660 quantify how much of this estimated organic carbon must have been lost through

661 remineralization to reconcile the observed wt.\% TOC within these strata. To do so, we

662 use a Redfield stoichiometry (Redfield, 1958) to relate the measured sedimentary weight

663 percent phosphorus to the associated flux of organic carbon necessary for this phosphorus

664 delivery. Redfield stoichiometry varies in space and time due to, for instance, taxonomic

665 variability in biomolecular and cellular composition and nutrient availability regulating

666 biosynthetic allocation (e.g., Geider and LaRoche, 2002). Moreover, water-column

667 heterotrophy increases the C:P ratio of particulate organic carbon delivered to the

668 sediment-water interface (Clark et al., 1998). To be conservative, we assume no water-

669 column remineralization and adopt the canonical Redfield ratio (106C:1P) in the

670 calculations below. We also adopt the combined organic-bound and authigenic

671 phosphorus phases determined from the phosphorus speciation extraction as an estimate

672 of the original flux of phosphorus delivered to the sediment via organic matter. This

673 calculation provides a conservative estimate because we neglect iron-adsorbed and

674 carbonate-bound $\mathrm{P}$ as potential sources for authigenic apatite (as these can represent 
675 primary sources of phosphorus to the sediment column), and we assume no diffusive loss

676 of phosphate from pore-water contemporaneous with sedimentary apatite authigenesis.

677 Following the above arguments, our estimate for the weight percent organic

678 carbon delivered to the sediment column $\left(\hat{C}_{\text {org }}^{*}\right)$ that can account for the measured

679 phosphorus content is given by:

$680 \quad \hat{C}_{\text {org }}^{*}=\left(P_{x l}+P_{\text {org }}\right) \times R \times\left(\frac{\alpha_{c}}{\alpha_{p}}\right)$

681 where $\mathrm{R}$ is the adopted Redfield ratio and $\alpha_{C}$ and $\alpha_{P}$ represent the molar weights of

682 carbon and phosphorus, respectively (Slomp et al., 2004). We estimate the percentage of

683 organic carbon remineralization necessary to reconcile the difference between the

684 delivery estimate, $\hat{C}_{\text {org }}^{*}$, and the measured wt.\% total organic carbon $\left(C_{\text {org }}\right)$ within

685 Thorntonia and Arthur Creek rocks (Slomp et al., 2004) as:

$686 \quad \%$ loss of $\hat{C}_{\text {org }}^{*}=\left(\frac{\hat{C}_{\text {org }}^{*}-C_{\text {org }}}{\hat{C}_{\text {org }}^{*}}\right) \times 100$

687 This value represents an estimate of organic carbon remineralization in the time between

688 delivery to the sediment-water interface and lithification. Applying these equations to

689 samples within the phosphorus-enriched middle and upper Thorntonia yields a median

$690 \hat{C}_{\text {org }}^{*}$ of 18.6 wt.\% and a median loss of $97.8 \%$ of this estimated delivery flux (Fig. 7). For

691 comparison, applying these equations to samples from the Arthur Creek indicates a

692 median organic carbon loss estimate of $74.0 \%$ from a median organic carbon delivery

693 estimate, $\hat{C}_{\text {org }}^{*}$, of only 1.1 wt.\% (Fig. 7). If, instead, we consider more typical ratios of

$694 \mathrm{C}_{\text {org }}: \mathrm{P}_{\text {org }}$ delivered to the sediment column, that is, C:P >> 106:1 (Ingall et al., 1993; Van

695 Cappellen and Ingall, 1996; Clark et al., 1998; Algeo and Ingall, 2007), then the required 
$696 \mathrm{C}_{\text {org }}$ delivery $\left(\hat{C}_{\text {org }}^{*}\right.$ ) and the estimated $\% \hat{C}_{\text {org }}^{*}$ loss increase proportionally. Likewise, any

697 diffusive/advective loss of phosphate from the sediment column prior to lithification

698 (Ingall et al., 1993; Slomp et al. 2002; 2004) would increase the requisite $\hat{C}_{\text {org }}^{*}$ and, thus,

699 the inferred \% $\hat{C}_{\text {org }}^{*}$ loss.

700 If organic carbon represented the sole delivery source of phosphorus to the

701 sediment column, what would have been the oxidant demand for the organic carbon

702 remineralization estimated above? Dissimilatory microbial metabolisms couple the

703 remineralization of sedimentary organic carbon to the reduction of an oxidant (primarily

$704 \mathrm{O}_{2}, \mathrm{NO}_{3}{ }^{-}, \mathrm{SO}_{4}{ }^{2-}$, and $\mathrm{Fe}^{3+}$; Konhauser, 2007). Thus, a portion of the estimated organic

705 carbon loss can be accounted for in the early diagenetic minerals pyrite and siderite,

706 which form from microbial dissimilatory sulfate and ferric iron respiration, respectively.

707 In the following calculations, we assume the stoichiometry of Fe-(oxyhydr)oxide

708 reduction, where one mole of organic carbon is remineralized per four moles of siderite

709 produced:

710

$$
\mathrm{CH}_{2} \mathrm{O}+8 \mathrm{H}^{+}+4 \mathrm{Fe}(\mathrm{OH})_{3} \Rightarrow 4 \mathrm{Fe}^{2+}{ }_{(\mathrm{aq})}+\mathrm{CO}_{2}+11 \mathrm{H}_{2} \mathrm{O}
$$

711

$$
4 \mathrm{Fe}^{2+}{ }_{(\mathrm{aq})}+4 \mathrm{CO}_{2}+4 \mathrm{H}_{2} \mathrm{O} \Rightarrow 4 \mathrm{FeCO}_{3}+8 \mathrm{H}^{+},
$$

712 and sulfate reduction, where four moles of organic carbon are remineralized per mole of

713 pyrite produced:

$714 \quad 4 \mathrm{CH}_{2} \mathrm{O}+2 \mathrm{SO}_{4}{ }^{2-} \Rightarrow 2 \mathrm{H}_{2} \mathrm{~S}+4 \mathrm{HCO}_{3}{ }^{-}$

715

$$
\mathrm{Fe}^{2+}{ }_{(\mathrm{aq})}+2 \mathrm{H}_{2} \mathrm{~S} \Rightarrow \mathrm{FeS}_{2}+4 \mathrm{H}^{+}
$$

716 We note that if $\mathrm{Fe}^{2+}$ for pyrite formation were also reduced locally it would require

717 additional $\mathrm{C}_{\text {org }}$ consumption, akin to Eqn. (3). 
719 molar quantity of siderite to the $\mathrm{Fe}^{3+}$ respiration stoichiometries of Eqns. 3 and 4 to

720 estimate the necessary weight percent of organic carbon consumed to produce this

721 siderite $\left(C_{\text {siderite }}\right)$ :

$$
C_{\text {siderite }}=\left(\frac{\left[\text { measured siderite }(\text { mol }) \times\left(\frac{1 \text { mol } \text { org }}{4 \text { mol siderite }}\right)\right] \times \gamma}{\text { sample weight }(g)}\right) \times 100
$$

723 where $\gamma$ converts measured values in moles to wt.\%. Likewise, to correct for the presence

724 of pyrite, we relate the measured molar quantity of pyrite within each sample to the

725 stoichiometry of $\mathrm{SO}_{4}{ }^{2-}$ respiration (Eqns. 5 and 6) in order to estimate the weight percent

726 of organic carbon remineralized to produce this pyrite $\left(C_{\text {pyrite }}\right)$ :

$$
C_{\text {pyrite }}=\left(\frac{\left[\text { measured pyrite }(\text { mol }) \times\left(\frac{4 \text { mol } C_{\text {org }}}{1 \text { mol pyrite }}\right)\right] \times \gamma}{\text { sample weight }(g)}\right) \times 100 .
$$

728 Equation (8) does not account for any $\mathrm{C}_{\text {org }}$ consumed to reduce iron for pyrite (e.g., Eqn.

729 3). In this regard, Eqns. 8 and 9 conservatively underestimate the weight percent of

730 organic carbon remineralized to form pyrite for the case that iron was reduced locally,

731 rather than sourced as $\mathrm{Fe}^{2+}$.

732 With these estimates, we augment Eqn. (2) as:

$$
\left(\frac{\hat{C}_{\text {org }}^{*}-\left(C_{\text {org }}+C_{\text {pyrite }}+C_{\text {siderite }}\right)}{\hat{C}_{\text {org }}^{*}}\right) \times 100 .
$$

734 This exercise yields a corrected median $\% \hat{C}_{\text {org }}^{*}$ loss for the middle and upper Thorntonia 735 members of $96.2 \%$, not significantly different than the estimate from Eqn. 2 (Fig. 7). In

736 contrast, and with the exception of phosphorus-enriched samples in the uppermost

737 measured meters, the corrected median loss for the Arthur Creek indicates that there is an 
738 excess wt.\% of organic carbon to account for the observed wt.\% phosphorus (Fig. 7).

739 However, the observed quantity of siderite within Thorntonia and Arthur Creek samples

740 may represent a late diagenetic addition to the sediment column and, thus, may not have

741 formed through local iron respiration consuming $\mathrm{C}_{\text {org }}$. If this were the case, the $\% \mathrm{C}_{\text {org }}$

742 loss would be less than the value estimated by Eqn. (9), and closer to the value

743 determined by Eqn. (2).

744 With sulfate and ferric iron accounted for, the only quantitatively important

745 remaining oxidant is molecular oxygen (Konhauser, 2007). In this regard, and if the

746 above assumptions hold, the implication is that the majority of the hypothesized organic

747 carbon loss was through respiration using molecular oxygen. We define a ratio of the

748 estimate of organic matter consumed through anoxic respiration (that is, with $\mathrm{Fe}^{3+}$ and

$749 \mathrm{SO}_{4}{ }^{2-}: \mathrm{C}_{\text {siderite }}$ and $\mathrm{C}_{\text {pyrite, }}$, respectively) to the estimate of $\mathrm{C}_{\text {org }}$ loss not accounted for by

750 this estimated anoxic remineralization. We calculate the ratio of anoxic to oxic

751 respiration as:

$752 \quad \frac{\text { anoxic }}{\text { oxic }}$ respiration $=\frac{C_{\text {pyrite }}+C_{\text {siderite }}}{\hat{C}_{\text {org }}^{*}-\left(C_{\text {org }}+C_{\text {pyrite }}+C_{\text {siderite }}\right)}$.

753 In solving Eqn. $(10)$, we obtain a median $\left(1^{\text {st }}, 3^{\text {rd }}\right.$ quartile $)$ value of $0.02(0.1,0.4)$ for the

754 middle and upper Thorntonia members. This is to say that a median $2 \%$ of the estimated

755 organic carbon delivery required to source the observed phosphorus content was

756 remineralized through anoxic pathways—98\% must have been remineralized with

757 molecular oxygen to explain the absence of this organic carbon from measured samples.

758 If, however, one assumes a diffusive loss of either sulfide or ferrous iron from the

759 sediment column (i.e., the numerator underestimates the organic carbon consumed by

760 anoxic remineralization), the estimated percent of anoxic remineralization becomes a 
761 minimum. If such diffusive loss occurred, then the proportion of $\mathrm{C}_{\text {org }}$ remineralized

762 through oxic respiration would be less than $98 \%$ and approach $0 \%$ as the sedimentary

763 production of sulfide and/or $\mathrm{Fe}^{2+}$ through microbial dissimilatory redox reactions

764 quantitatively consumed $\hat{C}_{\text {org }}^{*}$. While we cannot determine the diffusive flux of

765 reductants from Thorntonia or Arthur Creek sediments based on preserved geochemical

766 signals, we note that such a diffusive loss would be possible if the redox boundary

767 resided within the water column.

768 The calculated weight percent organic carbon required to deliver the observed

769 phosphorus is notable; the median value, $18.6 \mathrm{wt} . \%$, exceeds organic carbon export to the

770 sea floor in most modern marine environments (Hedges and Keil, 1995). While such low

771 organic carbon preservation efficiencies (or, as we describe, high $\% \hat{C}_{\text {org }}^{*}$ loss estimates)

772 commonly occur within modern marine environments, they typify depositional

773 environments with low sediment accumulation rates $(<\sim 0.02 \mathrm{~cm} / \mathrm{yr})$ or oxygenated shelf

774 settings (> $20 \mu \mathrm{M}$ bottom-water $\mathrm{O}_{2}$; Canfield, 1994; Hedges and Keil, 1995). While we

775 cannot provide unequivocal evidence that substantial aerobic carbon respiration did not

776 consume most of the $\mathrm{C}_{\text {org }}$ originally delivered to the Thorntonia sediment column, we

777 find it difficult to reconcile how such substantial aerobic respiration could have

778 proceeded without concurrently driving the sediment column anoxic, providing a

779 negative feedback on the efficiency of organic carbon respiration. Moreover, we note that

780 the oxidant demand to remineralize this magnitude of organic carbon is difficult to

781 reconcile with Cambrian oxygen levels, perhaps $15-50 \%$ present atmospheric

782 concentrations (Dahl et al., 2010; Bergman et al., 2004; for alternative views, see Berner,

783 2006; Garrels and Lerman, 1984). Nevertheless, it remains a possibility that episodes of 
784 intense aerobic respiration - and efficient capture of released $\mathrm{P}$ within authigenic

785 phases—account for Thorntonia Limestone phosphatic carbonate precipitation (although

786 see Föllmi et al. (2005) for discussion of a Miocene phosphogenic episode in which P

787 sourced from aerobic respiration was ruled out). If, however, one accepts the conclusion

788 that organic burial alone does not provide an adequate source of phosphorus to the

789 sediment column, then an additional source of $\mathrm{P}$ must have been present during

790 Thorntonia deposition.

791 Phosphorus adsorbed onto and/or co-precipitated with metal oxide particles

792 provides a second potential source of $\mathrm{P}$ to the sediment column whose importance

793 depends, in part, on the magnitude of the flux of metal oxides to the sediment column

794 (Shaffer, 1986; Feely et al., 1990; Feely et al., 1998; Poulton and Canfield, 2006).

795 Accordingly, we estimate phosphorus delivery under the assumption of an appreciable

796 iron-bound P flux, for simplicity based entirely on P adsorbed to iron (oxyhydr)oxides.

797 This assumption is consistent with the order-of-magnitude calculations presented above;

798 nonetheless, we acknowledge that other metal oxides, particularly manganese, play an

799 important role in the cycling of phosphorus (e.g., Dellwig et al., 2010).

800 Ideally, iron-speciation measurements could provide the basis for a quantitative

801 estimate of Fe-bound P delivered to the sediment column. But before we can perform

802 such a calculation, we ask whether the $\mathrm{Fe}_{\mathrm{ox}}, \mathrm{Fe}_{\mathrm{mag}}, \mathrm{Fe}_{\text {carb }}$, and $\mathrm{Fe}_{\mathrm{py}}$ pools as determined by

803 iron speciation in carbonate-rich strata of the Thorntonia Limestone and Arthur Creek

804 Formation reflect primary depositional reservoirs, or if post-depositional diagenesis could

805 have converted iron into, out of, or between these phases of the highly reactive iron pool?

806 Specifically, if these lithologies experienced closed system (with respect to mass) 
807 diagenetic remobilization of $\mathrm{Fe}$, then it is likely that appreciable amounts of Fe were

808 transferred between highly reactive iron phases (e.g., the formation of $\mathrm{Fe}_{\text {carb }}$ and $\mathrm{Fe}_{\mathrm{py}}$

809 through the reduction of an $\mathrm{Fe}_{\mathrm{ox}}$ precursor phase). In this regard, the value for $\mathrm{Fe}_{\mathrm{HR}}$ would

810 still accurately represent the primary iron pool—and could thus be used in calculations of

811 Fe-bound $\mathrm{P}$ delivery—however calculations involving any individual $\mathrm{Fe}_{\mathrm{HR}}$ phase (e.g.,

$\left.812 \mathrm{Fe}_{\mathrm{ox}}, \mathrm{Fe}_{\mathrm{carb}}\right)$ would not provide robust estimates of $\mathrm{Fe}$-bound P. Alternatively, if these

813 lithologies underwent open system diagenesis, the resulting addition or loss of Fe from

814 the $\mathrm{Fe}_{\mathrm{HR}}$ pool (from any and/or all constituent phases) would render any calculation based

815 on the iron speciation data suspect. While we cannot eliminate the possibility of $\mathrm{Fe}$

816 addition during open system diagenesis, we note that Fe-speciation data for the

817 Thorntonia Limestone and Arthur Creek Formation are consistent with other redox

818 proxies (see above) favoring the view that the highly reactive iron species to these rocks

819 record a substantial depositional flux.

820 In the following discussion we provide a methodology to address the potential

821 contribution of the Fe-P shuttle to Thorntonia and Arthur Creek sediments under the

822 assumption of limited or closed system iron diagenesis. To this end, we employ iron

823 speciation data from these lithologies for illustrative calculations. These calculations

824 provide a consistency argument given that organic-bound $\mathrm{P}$ was likely insufficient to

825 account for the measured P content. Throughout this discussion, we introduce and

826 emphasize the caveats inherent to the use of a diagenetically mobile element in these

827 calculations.

828 The molar ratio of the co-precipitation of phosphorus onto iron (oxyhydr)oxide

829 particles conforms to a distribution coefficient $\left(K_{\mathrm{D}}\right)$ model that scales linearly to the 
830 ambient seawater phosphate concentration $\left(\left[\mathrm{P}_{\mathrm{sw}}\right]\right)$ (Feely et al., 1991; 1998; Konhauser et

831 al., 2007):

$832\left(\frac{P}{F e}\right)_{\text {molar }}=K_{D} \times\left[P_{S W}\right]$.

833 Thus, to estimate the delivery of iron-bound phosphorus, $\hat{P}_{F e}^{*}$, we multiply an estimate of

834 iron oxide delivery $\left(\hat{F} e_{o x}^{*}\right)$ by the adsorption coefficient of phosphorus to iron oxides

$835\left(K_{\mathrm{D}}\right)$ for a given estimate of seawater phosphate concentration $\left(\left[\mathrm{P}_{\mathrm{sw}}\right]\right)$ :

$$
\hat{P}_{F e}^{*}=\gamma \hat{F} e_{o x}^{*} \times K_{D} \times\left[P_{S W}\right]
$$

837 where $\gamma$ converts measured values (in wt.\%) to moles as required in the definition of the 838 adsorption coefficient. Within anoxic pore-waters, a fraction of the iron oxides delivered 839 to the sediment column will be reduced by dissimilatory iron reduction and converted to

840 ferrous iron, and these ions will either precipitate as pyrite or iron carbonate, or

841 advect/diffuse to the overlying water column. Accordingly, a full accounting of $\hat{F} e_{o x}^{*}$

842 would include all of these conservation and loss terms. The estimate would become a

843 lower bound on $\hat{P}_{F e}^{*}$ if we ignored the ferrous iron loss flux, which in any event is

844 unconstrained, and included only the measured iron oxide $\left(\mathrm{Fe}_{\mathrm{ox}}\right)$, pyrite $\left(\mathrm{Fe}_{\mathrm{py}}\right)$ and iron-

845 carbonate phases $\left(\mathrm{Fe}_{\mathrm{carb}}\right)$. We note, however, that at least some of the measured $\mathrm{Fe}$ (most

846 obviously the $\mathrm{Fe}_{\text {carb }}$ phase) may have originated from diagenetic remobilization of iron to

847 these carbonates. (For the lower Thorntonia Limestone, $\mathrm{Fe}_{\text {carb }}$ comprises a median $\left(1^{\text {st }}, 3^{\text {rd }}\right.$

848 quartile) of $76.8 \%(71.3,81.8)$ of the total iron pool; in contrast, for the phosphatic

849 middle/upper Thorntonia and for the Arthur Creek Formation, $\mathrm{Fe}_{\text {carb }}$ accounts for only 
851 calculation may overestimate $\hat{P}_{F e}^{*}$.

852 Magnetite may form through the reductive dissolution of mixed ferrous-ferric

853 oxide phases (e.g., Zegeye et al., 2012), and, as such, could be considered in the

854 summation of primary iron oxide minerals $\left(\hat{F} e_{o x}^{*}\right)$; however, magnetite may also form

855 during prograde metamorphism, in which case inclusion of this phase would over-

856 estimate the primary ferric iron flux to the sediment column. We include $\mathrm{Fe}_{\text {mag }}$ within our

857 calculation because the authigenic pathway likely exceeds weathering and metamorphic

858 overprints for this depositional environment. (Regardless, within NTGS 99/1 magnetite

859 represents a negligible component of $\mathrm{Fe}_{\mathrm{T}}$, therefore this assumption does not alter the

860 illustrative estimate for $\hat{P}_{F e}^{*}$.) Therefore, we rewrite Eqn (12) in the approximate form:

$$
\hat{P}_{F e}^{*}=\gamma\left(F e_{o x}+F e_{p y}+F e_{c a r b}+F e_{m a g}\right) \times K_{D} \times\left[P_{S W}\right]
$$

862 A host of seawater ions - notably silica, trace metals and rare earth elements -

863 compete with phosphorus for adsorption sites on the surface of iron oxide particles (e.g.,

864 Berner, 1973; Trocine and Trefry, 1988; Olivarez and Owen, 1989; Trefry and Metz,

865 1989; Feely et al., 1991; Feely et al., 1998; German et al., 1990; Konhauser et al., 2007).

866 Thus, the choice of $K_{\mathrm{D}}$ depends on the assumption of the seawater composition of

867 Cambrian oceans. As these element concentrations are broadly unknown for the

868 Paleozoic Era, we focus here only on the role of the major seawater constituent dissolved

869 silica in competition for iron-surface anion sites. Following Siever's (1992) inference of

870 cristobalite saturation for early Phanerozoic seawater $\left(\left[\mathrm{Si}_{\mathrm{Sw}}\right]=0.67 \mathrm{mM}\right)$, Konhauser et

871 al. (2007) determined experimentally a $K_{\mathrm{D}}=0.0108$ for ferrihydrite at this silica

872 saturation state. Notably, the linear range of the $K_{\mathrm{D}}$ model depends on the phosphorus 
873 concentration of ambient seawater. At cristobalite saturation, the linearity of the $K_{\mathrm{D}}$

874 model saturates above $\sim 5 \mu \mathrm{M}\left[\mathrm{P}_{\mathrm{sw}}\right]$. This is to say that the co-precipitation and delivery of

875 phosphorus bound to iron oxides remains constant at and above this ambient seawater

876 phosphate concentration.

877 Hence, we adopt $\left[\mathrm{P}_{\mathrm{sw}}\right]=5 \mu \mathrm{M}$ to calculate a maximum estimate for $\hat{P}_{F e}^{*}$ at the

878 adopted $\left[\mathrm{Si}_{\mathrm{SW}}\right]$. We emphasize that the chosen value of $5 \mu \mathrm{M}$ is a simplistic assumption

879 and that water column phosphorus concentrations are affected by variable environmental

880 factors that are difficult to generalize, even under well-constrained modern conditions.

881 Nevertheless, this adopted phosphate concentration is consistent with modern anoxic

882 environments, including the Black Sea and Cariaco Basin (Shaffer, 1986; Scranton et al.,

883 2006). For example, in the Black Sea, higher phosphate concentrations in the ferruginous

884 chemocline than in the underlying sulfidic waters result from the dissolution of settling

885 Fe-oxides and the release of adsorbed phosphate (Brewer and Murray, 1973). Similar

886 processes are suggested to explain the phosphate concentrations (up to $9 \mu \mathrm{M}$ dissolved P)

887 in the ferruginous Lake Matano (Crowe et al., 2008) where the release of $\mathrm{Fe}(\mathrm{III})$-bound $\mathrm{P}$

888 at the chemocline is balanced by the precipitation of Fe(II)-phosphates below the

889 chemocline.

890 Applying Eqn. (13) to samples from the middle and upper Thorntonia members

891 yields a median estimate for iron-bound $\mathrm{P}$ of $0.1 \mathrm{wt} . \%$ as compared to a median estimate

892 of 0.2 wt.\% for the Arthur Creek (Fig. 7). In this formulation, phosphorus delivery by

893 iron oxides is proportional to the highly reactive iron phases $\left(\mathrm{Fe}_{\mathrm{HR}}\right)$ determined from iron

894 speciation geochemistry. While $\mathrm{Fe}_{\mathrm{HR}} / \mathrm{Fe}_{\mathrm{T}}$ decreases between the P-enriched middle /

895 upper Thorntonia members and the Arthur Creek, the observed increase in $\mathrm{Fe}_{\mathrm{T}}$ within the 
896 Arthur Creek compensates such that the molar estimate of $\hat{F} e_{o x}^{*}$, and, thus, $\hat{P}_{F e}^{*}$ remains

897 roughly constant between the two formations. As such, and if the above assumptions

898 hold, this implies that the relative contribution of the Fe-P shuttle to the observed weight

899 percent sedimentary P was much greater during deposition of the Arthur Creek Formation

900 because of the lower wt.\% $\mathrm{P}_{\mathrm{T}}$ measured throughout this formation. Indeed, the median

901 estimate of $\hat{P}_{F e}^{*}=0.2$ wt.\% for the Arthur Creek greatly exceeds the median measured $\mathrm{P}_{\mathrm{T}}$

902 (0.03 wt.\%; Fig. 7). In contrast, the median estimate of $\hat{P}_{F e}^{*}=0.1$ wt.\% for the middle and

903 upper Thorntonia members provides only $\sim 10 \%$ of the median measured $\mathrm{P}_{\mathrm{T}}(0.98$ wt. $\%$;

904 Fig. 7), and proportionally less for samples with the highest measured $\mathrm{P}_{\mathrm{T}}$ approaching 4

905 wt.\%. Likewise, any diffusive loss of $\mathrm{P}$ from the sediment column prior to lithification

906 would increase the requisite $\hat{P}_{F e}^{*}$ and, in the case of the Thorntonia, increase the

907 deficiency between the observed $\mathrm{P}_{\mathrm{T}}$ and $\mathrm{P}$ hypothesized to have been delivered associated 908 with $\mathrm{Fe}_{\mathrm{ox}}\left(\hat{P}_{\mathrm{Fe}}^{*}\right)$.

909 The formulation of our equations may significantly overestimate Fe-bound P

910 delivery for two reasons. First, our calculations adopt a $K_{\mathrm{D}}$ value based on an estimate of

911 contemporaneous seawater silica concentrations. Second, our calculations adopt a

912 seawater phosphate concentration that maximizes the potential for phosphorus delivery

913 by the iron shuttle. If we presumed a higher seawater silica concentration (that is,

914 decreased $K_{\mathrm{D}}$ ), or if, for an assumed [Sisw], we also assumed a lower $\left[\mathrm{P}_{\mathrm{SW}}\right]$, then we

915 would calculate a lower P delivery flux per unit $\mathrm{Fe}_{\mathrm{ox}}$. Thus, both of these changes would

916 yield a lower estimate of $\hat{P}_{F e}^{*}$ for a given iron flux to the sediment column. 
918 capacity for iron minerals to scavenge and deliver phosphorus to the sea floor depends on

919 a number of factors, including the surface density of adsorption sites, which in part is

920 related to mineral surface area. In this regard, amorphous to poorly crystalline phases will

921 scavenge more phosphate than highly crystalline phases. (We note, however, that

922 progressive crystallization may result in the subsequent desorption of $\mathrm{P}$ from adsorption

923 sites. If this desorption occurs within the sediment column, outside the length-scales of

924 advection/diffusion with the overlying water-column, Fe-bound P could provide a

925 significant source of $\mathrm{P}$ to the sediment column.) Here we assumed ferrihydrite as the

926 carrier phase (Konhauser et al., 2007), however, a range of other iron minerals form

927 during anaerobic $\mathrm{Fe}^{2+}$ oxidation (e.g., Kappler and Newman, 2004; Zegeye et al., 2012).

928 For instance, in the only detailed study of Fe mineralogy in a ferruginous water column

929 (Lake Matano, Indonesia), Zegeye et al. (2012) found that ferrihydrite was quantitatively

930 transformed to carbonated green rust ('fougerite') during settling through the water

931 column, with more minor formation of magnetite. Unfortunately, no experimental data

932 currently exist for $\mathrm{P}$ adsorption to green rust under the chemical conditions likely

933 encountered in Cambrian oceans (e.g., Lake Matano has relatively low [Si]). However,

934 adsorption of oxyanions to green rust tends to be far higher than for ferrihydrite (Randall

935 et al., 2001), and thus such a finding highlights the need to consider multiple and varied

936 carrier phases for the ancient Fe-P shuttle. An iron carrier phase with an adsorption

937 coefficient $\left(K_{\mathrm{D}}\right)$ with respect to $\mathrm{P}$ greater than ferrihydrite could have delivered more $\mathrm{P}$ to

938 Thorntonia sediments for a given iron flux to the sea floor. 
940 greater than that inferred from the formulations of equations 11 through 13 ? To answer

941 this question it is necessary to address whether the measured $\mathrm{Fe}_{\mathrm{HR}}$ is an accurate proxy

942 for the contribution of $\mathrm{Fe}_{\mathrm{ox}}$ to the sediment column, or whether it could underestimate the

943 original $\mathrm{Fe}_{\mathrm{ox}}$ flux $\left(\hat{F} e_{o x}^{*}\right)$, and, thus, $\hat{P}_{F e}^{*}$ to the sediment column. Next, we explore

944 hypothetical redox scenarios in which Fe-bound $\mathrm{P}$ could contribute more substantially to

945 authigenic apatite. Without an independent line of evidence that the constituent phases of

946 the highly reactive iron pool represent the primary fluxes of iron to the sediment column,

947 we choose not to advocate for this possibility for the Thorntonia Limestone.

948 Nevertheless, with regard to the broader question of the mechanism for phosphatic

949 carbonate deposition, we find it informative to evaluate the circumstances in which the

950 Fe-bound delivery shuttle could contribute substantially to phosphogenesis and

951 phosphatic carbonate deposition.

952 One can envision a spectrum of scenarios for the relative magnitudes of $\mathrm{Fe}_{\mathrm{ox}}$

953 delivery to and $\mathrm{Fe}^{2+}$ loss from the sediment column. These scenarios fall within three

954 generalized categories: $\mathrm{Fe}_{\mathrm{ox}}$ delivery (1) greater than, (2) nearly equal to, or (3) less than

$955 \mathrm{Fe}^{2+}$ diffusive/advective loss. In the following discussion we discount scenario (3)

956 because such an imbalance defines an unsustainable Fe cycle. To begin, we consider the

957 scenario that (1) $\mathrm{Fe}_{\mathrm{ox}}$ delivery exceeds $\mathrm{Fe}^{2+}$ loss. This can result from two opposing redox

958 regimes. (1a) If the majority of $\mathrm{Fe}_{\mathrm{ox}}$ delivered to the sediment column were stabilized

959 within oxygenated pore-water then this would preclude widespread iron reduction. In this

960 instance, only a small amount $\mathrm{P}$ would be liberated from the $\mathrm{Fe}_{\mathrm{ox}}$ delivery shuttle, and

$961 \mathrm{Fe}_{\mathrm{ox}}$ would dominate $\mathrm{Fe}_{\mathrm{HR}}$. (1b) Alternatively, if sedimentary electron donors (e.g., $\mathrm{C}_{\mathrm{org}}$ ) 
962 contributed to pore-water anoxia, some fraction of the delivered $\mathrm{Fe}_{\mathrm{ox}}$ would be reduced to

$963 \mathrm{Fe}^{2+}$, and any $\mathrm{P}$ bound to these $\mathrm{Fe}_{\mathrm{ox}}$ particles would be released to pore-waters. To

964 maintain the low $\mathrm{Fe}^{2+}$ loss fraction defining this scenario, any $\mathrm{Fe}^{2+}$ ions produced must be

965 captured quantitatively within authigenic ferrous iron minerals. In this instance,

966 sedimentary Fe would be partitioned amongst $\mathrm{Fe}_{\mathrm{ox}}, \mathrm{Fe}_{\mathrm{carb}}$, and $\mathrm{Fe}_{\mathrm{py}}$ phases, and the

967 dominance of the latter two minerals would imply that much of the original $\mathrm{Fe}_{\mathrm{ox}}$ flux was

968 reduced. Notably, with regard to $\mathrm{P}$ delivery, either scenario for high $\mathrm{Fe}_{\mathrm{ox}}$ delivery relative

969 to $\mathrm{Fe}^{2+}$ loss predicts that the measurement of sedimentary $\mathrm{Fe}_{\mathrm{HR}}$ represents a close

970 approximation of the magnitude of $\mathrm{P}$ delivery associated with the Fe-P shuttle $\left(\hat{P}_{F e}^{*}\right)$. If,

971 for example, the Fe cycle were operating in this manner at the time of deposition of the

972 middle and upper Thorntonia members then, under the above assumptions, the Fe-shuttle

973 would be constrained to have contributed a median of $\sim 10 \% \mathrm{P}_{\mathrm{T}}$ (as determined from Eqn.

974 13) and, therefore, could not represent a dominant source of $\mathrm{P}$ for the observed

975 enrichment.

976 If scenarios $1 \mathrm{a}$ and $1 \mathrm{~b}$ cannot source significant amounts of Fe-bound $\mathrm{P}$ to

977 phosphatic lithologies, can scenario 2? Like scenario (1b) above, scenario (2) necessitates

978 a redox environment that facilitates the reductive dissolution of the majority of $\mathrm{Fe}_{\mathrm{ox}}$

979 delivered to the sediment column, regardless of the size of this flux. In contrast, scenario

980 (2) is distinguished from scenario (1) by the condition that the majority of the

981 sedimentary $\mathrm{Fe}^{2+}$ produced must escape to the overlying water column, resulting in less

982 capture of $\mathrm{Fe}^{2+}$ ions in authigenic minerals. Such diffusive loss requires anoxia within the

983 water-mass overlying the sediment column. As above, Fe retained within the sediment

984 can reside in any combination of $\mathrm{Fe}_{\mathrm{ox}}, \mathrm{Fe}_{\mathrm{carb}}$, and/or $\mathrm{Fe}_{\mathrm{py}}$ phases. Notably, Scenario (2) 
985 allows for the measured $\mathrm{Fe}_{\mathrm{HR}}$ value to significantly underestimate iron oxide delivery to

986 the sea floor $\left(\hat{F}_{o x}^{*}\right)$ and, therefore, to underestimate the Fe-P shuttle $\left(\hat{P}_{F e}^{*}\right)$. If, for

987 example, the $\mathrm{Fe}$ cycle were operating with an extensive benthic flux of $\mathrm{Fe}^{2+}$ to the water

988 column during deposition of the middle Thorntonia Limestone, and if a mechanism

989 existed to preferentially retain the delivered $\mathrm{P}$, then the Fe-P shuttle could have provided

990 a significant proportion of the observed $\mathrm{P}$ to these phosphatic strata, that is, greater than

991 the $\sim 10 \%$ estimated from Eqn. (13).

992 In summary, simple models of Fe-bound P delivery estimates $\left(\hat{P}_{F e}^{*}\right)$, as determined

993 from Eqn. (13), indicate that this delivery shuttle could have sourced the measured P

994 content of the Arthur Creek Formation. In contrast, our estimates of Fe-bound P can only

995 account for a median of $10 \%$ of the P content the Thorntonia Limestone. (This estimate

996 assumes that $\mathrm{Fe}_{\mathrm{HR}}$ in Thorntonia rocks reflects deposition from the water column. To the

997 extent that Thorntonia iron minerals reflect open-system diagenesis, this estimate would

998 be even lower.) Only by invoking a major diffusive loss of iron from the Thorntonia

999 sediment column with subsequent capture of delivered $\mathrm{P}$ within authigenic phases-a

1000 scenario for which we do not advocate, yet do not find inconsistent with the assumption

1001 of limited diagenesis - could Fe-bound P have provided a more substantial contribution

1002 to phosphatic carbonates of the Thorntonia Limestone.

1003

1004 CONCLUSIONS

1005 Within drill core NTGS 99/1, phosphorus enrichment is confined to the middle

1006 and upper members of the Thorntonia Limestone, and petrographic observations reveal

1007 that this enrichment reflects authigenic apatite mineral nucleation primarily associated 
1008 with the interior of bioclasts and, more rarely, as cement in bioclastic grainstone. Under

1009 the canonical model that phosphorus bound within organic matter represents the only

1010 significant delivery flux of phosphorus to the sediment column, molar $\mathrm{C}_{\text {org }}: \mathrm{P}_{\mathrm{T}}$ well below

1011 the Redfield ratio requires significant $\mathrm{C}_{\text {org }}$ loss or a second delivery source of phosphorus

1012 to Thorntonia sediments.

1013 Interpreted together, sedimentological observations and iron speciation data

1014 suggest that sediment within the southern Georgina Basin accumulated under anoxic,

1015 ferruginous conditions. This redox diagnosis is consistent with previous research

1016 documenting the propensity for anoxic, ferruginous conditions in subsurface water

1017 masses of late Neoproterozoic and Cambrian oceans (Canfield et al., 2008) driven by the

1018 relative fluxes of electron donors (organic carbon) and electron acceptors (reactive $\mathrm{Fe}$,

1019 sulfate) into a basin (Johnston et al., 2010). If correct, the conclusion of an active iron

1020 redox cycle contemporaneous with the deposition of the Thorntonia Limestone and

1021 Arthur Creek Formation provides a second mechanism for augmented sedimentary

1022 phosphorus delivery—phosphorus adsorbed to particulate iron minerals.

1023 The stoichiometries of delivery estimates and remineralization reactions indicate

1024 that the phosphorus content of the Arthur Creek Formation is easily accounted for by any

1025 combination of phosphorus associated with organic matter and/or iron oxide fluxes.

1026 However, the observed phosphorus content of the Thorntonia is difficult to reconcile with

1027 reasonable fluxes of either organic-bound or iron-bound phosphorus alone. Thus, we

1028 suggest that both sources were necessary to account for Thorntonia Limestone phosphatic

1029 carbonate deposition. 
1031 history speaks to discontinuous mechanisms of formation. We hypothesize that redox-

1032 mediated phosphorus delivery via the Fe-P shuttle, rather than a discontinuous organic

1033 carbon flux, provides the more intermittent mechanism for phosphorus delivery to the

1034 sediment column. That said, ferruginous bottom waters appear to have been widespread

1035 in Proterozoic oceans, whereas phosphatic carbonates are not. Thus, the episodic nature

1036 of phosphate deposition must additionally depend on the fate of phosphate after it enters

1037 the sediment column. Where the oxic-anoxic interface lies well within the water column,

1038 microbial reduction of ferric iron within the sediments will remobilize $\mathrm{P}$, with a high

1039 probability of escape back to the water column. Where phosphate in solution is trapped

1040 by skeletons, however, or bound to decay-resistant materials such as chitinous

1041 exoskeletons, mineral phosphate may be reprecipitated in sediments. With this in mind,

1042 it would appear that delivery mechanisms, post-delivery fate within sediments, and

1043 evolution all contributed to the observed geological record of Cambrian phosphate

1044 accumulation.

1045

\section{ACKNOWLEDGMENTS}

1047 We thank the Northern Territory Geological Survey and Max Heckenberg and Jay Carter

1048 of the Alice Springs Core Library for generous access to core material. The Agouron

1049 Institute and the NASA Astrobiology Institute (MIT node) provided financial support.

1050 We thank Paul Myrow for discussions of sedimentology, Eric Morrow for assistance with

1051 data analysis, Greg Eischeid for technical support in the Harvard University Laboratory

1052 for Geochemical Oceanography, and David Fike and an anonymous reviewer for critical

1053 comments that helped to improve this paper. 


\section{REFEENCES CITED}

1056 Algeo, T.J., and Ingall, E., 2007, Sedimentary $\mathrm{C}_{\text {org:P }}$ Patios, paleocean ventilation, and Phanerozoic atmospheric $p \mathrm{O}_{2}$ : Palaeogeography, Palaeoclimatology, Palaeoecology v. p.

1058

1059

1060 130-155, doi.10.1016/j.palaeo.2007.02.029.

1061

Ambrose, G., and Putnam, P., 2006, The Georgina Basin 2006: Northern Territory of

1062

1063

1064

1065

1066

1067

1068

1069

1070

1071

1072

1073

1074

1075

1076

1077

1078

1079

1080

1081

1082

1083

1084

1085

1086

1087

1088

1089

1090

1091

1092

1093

1094

1095

1096

1097 Australia onshore hydrocarbon potential: Northern Territory Geological Survey, Record 2006-003.

Ambrose G.J., Kruse P.D., and Putman P.E., 2001, Geology and hydrocarbon potential of the southern Georgina Basin, Australia: Australian Petroleum Production and Exploration Association Journal, v. 41, p. 139-163.

Anderson L. D., Delaney M. L. and Faul K. L., 2001, Carbon to phosphorus ratios in sediments: implications for nutrient cycling: Global Biogeochemical Cycles, v. 15, p. 6579, doi:10.1029/2000GB001270.

Anderson, T.F., and Raiswell, R., Sources and mechanisms for the enrichment of highly reactive iron in euxinic Black Sea sediments: American Journal of Science, v. 304, p. 203-233, doi:10.2475/ajs.304.3.203.

Babcock, L.E., and Shanchi Peng, 2007, Cambrian chronostratigraphy: Current state and future plans: Palaeogeography, Palaeoclimatology, Palaeoecology, v. 254, p. 62-66, doi:10.1016/j.palaeo.2007.03.011.

Bartley, J.K., Pope, M., Knoll, A.H., Semikhatov, M.A., and Petrov, P.Yu., 1998, A Vendian-Cambrian boundary succession from the northwestern margin of the Siberian Platform: stratigraphy, palaeontology, chemostratigraphy and correlation: Geological Magazine, v. 135, p. 473-494, doi:10.1017/S0016756898008772.

Baturin, G. N., and Bezrukov, P. L., 1979, Phosphorites on the sea floor and their origin: Marine Geology, v. 31, p. 317-332, doi: 10.1016/0025-3227(79)90040-9.

Bengtson, S., and Yue Zhao, 1997, Fossilized metazoan embryos from the earliest Cambrian: Science, v. 277, p. 1645-1648, doi:10.1126/science.277.5332.1645.

Bengtson, S., Conway Morris, S., Cooper, B.J., Jell, P.A., and Runnegar, B.N., 1990, Early Cambrian Fossils from South Australia: Memoirs of the Association of Australasian Palaeontologists, v. 9, p. 1-364.

Benitez-Nelson, C.R., 2000, The biogeochemical cycling of phosphorus in marine systems: Earth-Science Reviews, v. 51, p. 109-135, doi: 10.1016/S0012-

1098 
Bergman, N.M., Lenton, T.M., and Watson, A.J., 2004, COPSE: A new model of biogeochemical cycling over Phanerozoic time: American Journal of Science, v. 304, p. 397-437, doi: 10.2475/ajs.304.5.397.

Berner, R. A., 1973, Phosphate removal from sea water by adsorption on volcanogenic ferric oxides: Earth and Planetary Science Letters, v. 18, p. 77-86, doi: 10.1016/0012$821 X(73) 90037-X$.

Berner, R.A., 2006, GEOCARBSULF: A combined model for Phanerozoic atmospheric

Bjerrum, C.J., and Canfield, D.E., 2002, Ocean productivity before about 1.9 Gyr ago limited by phosphorus adsorption onto iron oxides: Nature, v. 417 p. 159-162, doi:10.1038/417159a.

Boreham, C.J., and Ambrose, G.J., 2005, Cambrian petroleum systems in the southern Georgina Basin, Northern Territory, Australia, Central Australian Basins Symposium: petroleum and minerals potential, Alice Springs, NT, 16-18 August 2005.

Brewer, P.G., and Murray, J.W., 1973, Carbon, nitrogen and phosphorus in the Black Sea: Deep-Sea Research, v. 20, p. 803-818.

Brasier, M.D., and Callow, R.H.T., 2007, Changes in the Patterns of Phosphatic Preservation across the Proterozoic-Cambrian Transition: Memoirs of the Association of Australasian Palaeontologists, No. 34, p. 377-389.

Butterfield, N.J., 2003, Exceptional fossil preservation and the Cambrian explosion: Integrative and Comparative Biology, v. 43, p. 166-177, doi: 10.1093/icb/43.1.166.

Canfield, D.E., 1994, Factors influencing organic carbon preservation in marine sediments: Chemical Geology, v. 114 p. 315-329, doi: 10.1016/0009-2541(94)90061-2.

Canfield, D.E., Lyons, T.W., and Raiswell, R., 1996, A model for iron deposition to euxinic Black Sea sediments: American Journal of Science, v. 296, p. 818-834.

Canfield, D.E., Poulton, S.W., Knoll, A.H., Narbonne, G.M., Ross, G., Goldberg, T., and Strauss, H., 2008, Ferruginous conditions dominated later Neoproterozoic deep-water chemistry: Science, v. 321, p. 949-952, doi: 10.1126/science.1154499. minerals towards sulfide: American Journal of Science v. 292, p. 659- 683.Canfield D. E., Raiswell R., Westrich J. T., Reaves C. M. and Berner R. A., 1986, The use of chromium reduction in the analysis of reduced inorganic sulfur in sediments and shales: Chemical Geology, v. 54, p., 149-155, doi: 10.1016/0009-2541(86)90078-1. 
1145 Clark, L.L., Ingall, E.D., and Benner, R., 1998, Marine phosphorus is selectively

1146 remineralized: Nature, v. 393, p. 426-426 doi:10.1038/30881.

Cook, P.J., 1992, Phosphogenesis around the Proterozoic-Phanerozoic transition: Journal of the Geological Society of London, v. 149, p. 615-620, doi: 10.1144/gsjgs.149.4.0615

Cook, P.J., and McElhinny, M.W., 1979, A re-evaluation of the spatial and temporal distribution of sedimentary phosphate deposits in the light of plate tectonics: Economic Geology and the Bulletin of the Society of Economic Geologists, v. 74, p. 315-330, doi: 10.2113/gsecongeo.74.2.315.

Cook, P., and Shergold, J.H., 1984, Phosphorus, phosphorites and skeletal evolution at the Precambrian-Cambrian boundary: Nature v.10, p. 231-236, doi: 10.1038/308231a0.

Cook, P.J., and Shergold, J.H., 1986, Proterozoic and Cambrian phosphorites - nature and origin: in Cook, P.J., and Shergold, J.H., eds., Phosphate deposits of the word: Proterozoic and Cambrian phosphorites, Volume 1: Cambridge, UK, Cambridge University Press, p. 369-386.

Cook, P.J., Shergold, J.H., Burnett, W.C., and Riggs, S.R., 1990, Phosphorite research: a historical overview: Geological Society, London, Special Publication, v. 52, p. 1-22, doi: 10.1144/GSL.SP.1990.052.01.02.

Cordell, D., Drangert, J.-O., and White, S., 2009, The story of phosphorus: Global food security and food for thought: Global Environmental Change, v. 19, p. 292-305, doi: 10.1016/j.gloenvcha.2008.10.009.

Crowe, S.A., O’Neill, A.H., Katsev, S., Hehanussa, P., Haffner, G.D., Sundby, B., Mucci, A. and Fowle, D.A., 2008, The biogeochemistry of tropical lakes: a case study from Lake Matano, Indonesia: Limnology and Oceanography, v. 53, p. 319-331.

Dahl, T.W., Hammarlund, E.U., Anbar, A.D., Bond, D.P.G., Gill, B.C., Gordon, G.W., Knoll, A.H., Nielsen, A.T., Schovsbo, N.H., Canfield, D.E., 2010, Devonian rise in atmospheric oxygen correlated to the radiations of terrestrial plants and large predatory fish, v. 107, p. 17911-17915, doi: 10.1073/pnas.1011287107.

Delaney M.L., 1998, Phosphorus accumulation in marine sediments and the oceanic phosphorus cycle: Global Biogeochemical Cycles, v. 12, p. 563-572, doi:10.1029/98GB02263.

Dellwig, O., Leipe, T., März, C., Glockzin, M., Pollehne, F., Schnetger, B., Yakushev, E.V., Böttcher, M.E., and Brumsack, H.-J., 2010, A new particulate Mn-Fe-P-shuttle at the redoxcline of anoxic basins: Geochimica et Cosmochimica Acta, v. 74, p. 7100-7115.

Donoghue, P., Kouchinsky, A., Waloszek, D., Bengtson, S., Dong, X.-p., Val'kov, A.K., Cunningham, J.A., and Repetski, J.E., 2006, Fossilized embryos are widespread but the 
record is temporally and taxonomically biased: Evolution \& Development, v. 8, p. 232238, doi: 10.1111/j.1525-142X.2006.00093.x.

Dornbos, S.Q., Botjer, D.J., Chen, J.-Y., Gao, F., Oliveri, P., and Li, C.-W., 2006, Environmental controls on the taphonomy of phosphatized animals and animal embryos from the Neoproterozoic Doushantuo Formation, southwest China: Palaios, v. 21, p. 3-14, doi: 10.2110/palo.2004.p04-37.

Dunster, J.N., Kruse, P.D., Duffett, M.L., and Ambrose, G.J., 2007, Geology and resource potential of the southern Georgina Basin: Northern Territory Geological Survey, Digital Information Package DIP007.

Feely, R.A., Trefry, J.H., Massoth, G.J., and Metz, S., 1991, A comparison of the scavenging of phosphorus and arsenic from seawater by hydrothermal iron oxyhydroxides in the Atlantic and Pacific Oceans: Deep Sea Research, v. 38, p., 617-623, doi: 10.1016/0198-0149(91)90001-V.

Feely, R.A., Trefry, J.H., Lebon, G.T., and German, C.R., 1998, The relationship between $\mathrm{P} / \mathrm{Fe}$ and $\mathrm{V} / \mathrm{Fe}$ ratios in hydrothermal precipitates and dissolved phosphate in seawater: Geophysical Research Letters, v. 25, p. 2253-2256, doi:10.1029/98GL01546.

Filippelli, G.M., 2011, Phosphate rock formation and marine phosphorus geochemistry: the deep time perspective: Chemosphere, v. 84, p. 759-766, doi: 10.1016/j.chemosphere.2011.02.019.

Filippelli, G.M., and Delaney, M.L., 1992, Similar phosphorus fluxes in ancient phosphorite deposits and a modern phosphogenic environment: Geology, v. 20, p. 709712, doi: 10.1130/0091-7613(1992)020<070.

Föllmi, K.B., 1996, The phosphorus cycle, phosphogenesis and marine phosphate-rich deposits: Earth-Science Reviews, v. 40, p. 55-124, doi: 10.1016/0012-8252(95)00049-6.

Föllmi, K.B., Badertscher, C., de Kaenel, E., Stille, P., John, C. M., Adatte, T., and Steinmann, P, 2005), Phosphogenesis and organic-carbon preservation in the Miocene Monterey Formation at Naples Beach, California-The Monterey hypothesis revisited: Geological Society of America Bulletin, v. 117, p. 589-619, doi:10.1130/B25524.1.

Garrels, R.M., and Lerman, A., 1984, Coupling of the sedimentary sulfur and carbon cycles; an improved model: American Journal of Science, v. 284, p. 989-1007, doi: 10.2475/ajs.284.9.989.

Geider, R., and La Roche, J., 2002, Redfield revisited: variability of C:N:P in marine microalgae and its biochemical basis: European Journal of Phycology, v. 37, p. 1-17, doi: $10.1017 /$ S0967026201003456.

German, C.R., Klinkhammer, G.P., Edmond, J.M., Mitra, A., and Elderfield, H., 1990, 
1237 Hydrothermal scavenging of rare earth elements in the ocean: Nature, v. 345, p. 516-518, 1238 doi:10.1038/345516a0.

1239 Gomez, F.J., Ogle, N., Astini, R.A., and Kalin, R.M., 2007, Paleoenvironmental and Carbon-Oxygen Isotope Record of Middle Cambrian Carbonates (La Laja Formation) in the Argentine Precordillera: Journal of Sedimentary Research, v. 77, p. 826-842, doi: 10.2110/jsr.2007.079.

1243 Guo, H., Du, Y., Kah, L.C., Huang, J., Hu, C., Huang, H. and Yau, W., 2013, Isotopic 1244 composition of organic and inorganic carbon from the Mesoproterozoic Jixian Group, North China: Implications for biological and oceanic evolution: Precambrian Research, v. 224, p. 169-183, doi: 10.1016/j.precamres.2012.09.023.

1247 Guo, Q., Strauss, H., Liu, C., Zhao, Y., Yang, X., Peng, J., and Yang, H., 2010, A 1248 negative carbon isotope excursion defines the boundary from Cambrian Series 2 to 1249 Cambrian Series 3 on the Yangtze Platform, South China: Palaeogeography, 1250 Palaeoclimatology, Palaeoecology, v. 285, p. 143-151, doi:10.1016/j.palaeo.2009.11.005.

1251 Howard, P.F., 1990, The distribution of phosphatic facies in the Georgina, Wiso and Daly 1252 1253

1254 Hedges, J.I., and Kiel, R.G., 1995, Sedimentary organic matter preservation: an 1255 assessment and speculative synthesis: Marine Chemistry, v. 49, p.81-115, doi: 1256 10.1016/0304-4203(95)00008-F.

1257 Holland, H.D., 2006, The oxygenation of the atmosphere and oceans: Philosophical 1258 1259

Ingall, E.D., Bustin, R.M., and Van Cappellen, P., 1993, Influences of water column anoxia on the burial and preservation of carbon and phosphorus in marine shales:

Geochimica et Cosmochimica Acta, v. 57, p. 303-316, doi: 10.1016/00167037(93)90433-W.

Ingall E. D. and Jahnke R. A., 1997, Influence of water- column anoxia on the elemental fractionation of carbon and phosphorus during sediment diagenesis: Marine Geology, v. 139, p. 219-229, doi: 10.1016/S0025-3227(96)00112-0.

Jilbert, T., and Slomp, C.P., 2013, Iron and manganese shuttles control the formation of authigenic phosphorus minerals in the euxinic basins of the Baltic Sea: Geochimica et Cosmochimica Acta, v. 107, p. 155-169, doi: 10.1016/j.gca.2013.01.005.

Jilbert, T., Slomp, C.P., Gustafsson, B.G., and Boer, W., 2011, Beyond the Fe-P-redox connection: preferential regeneration of phosphorus from organic matter as a key control on Baltic Sea nutrient cycles: Biogeosciences, v. 8, p. 1699-1720, doi: 10.5194/bg-81277 
Johnston, D.T., Poulton, S.W., Dehler, C., Porter, S., Husson, J., Canfield, D.E., and Knoll, A.H., 2010, An emerging picture of Neoproterozoic ocean chemistry: Insights from the Chuar Group, Grand Canyon, USA: Earth and Planetary Science Letters, v. 290, p. 64-73, doi: 10.1016/j.eps1.2009.11.059.

Kappler, A., and Newman, D.K., 2004, Formation of Fe(III)-minerals by Fe(II)oxidizing photoautotrophic bacteria: Geochimica et Cosmochimica Acta, v. 68, p. 12171226, doi:10.1016/j.gca.2003.09.006.

Kazakov, A.V., 1937, The phosphate facies: Origin of phosphorites and geological factors of deposit formation: Proceedings of the Scientific Institute of Fertilizers and Insectofungicides, v. 145, p. 1-106.

Konhauser, K.O., 2007, Introduction to Geomicrobiology: Oxford, Blackwell Science, $425 \mathrm{p}$.

Konhauser, K.O., Lalonde, S.V., Amskold, L., and Holland, H.D., 2007, Was There Really an Archean Phosphate Crisis?: Science, v. 315, p. 1234, doi:

10.1126/science.1136328.

Kouchinsky, A., Bengtson, S., Runnegar, B., Skovsted, C., Steiner, M., and Vendrasco, M., 2012, Chronology of early Cambrian biomineralization: Geological Magazine, v. 149, p. 221-251, doi: 10.1017/S0016756811000720.

Krom, M.D., and Berner, R.A., 1981, The diagenesis of phosphorus in a nearshore marine sediment: Geochimica et Cosmochimica Acta, v. 45, p. 207-216, doi: 10.1016/0016-7037(81)90164-2.

Laurie, J.R., 2004a, Early Middle Cambrian trilobites from Pacific Oil \& Gas Baldwin 1 well, southern Georgina Basin, Northern Territory: Memoirs of the Association of Australasian Palaeontologists v. 32, p. 127-204.

Laurie, J.R., 2004b, Early Middle Cambrian trilobite faunas from NTGS Elkedra 3 corehole, southern Georgina Basin, Northern Territory: Memoirs of the Association of Australasian Palaeontologists, v. 30, p. 221-260.

Lindsay, J.F., 2002, Supersequences, superbasins, supercontinents - evidence from the Neoproterozoic-Early Palaeozoic basins of central Australia: Basin Research, v. 14, p. 207-223, doi: 10.1046/j.1365-2117.2002.00170.x.

Lindsay, J.F., Kruse, P.D., Green, O.R., Hawkins, E., Brasier, M.D., Cartlidge, J., and Corfield, R.M., 2005, The Neoproterozoic-Cambrian record in Australia: a stable isotope study: Precambrian Research, v. 143, p. 113-133, doi: 10.1016/j.precamres.2005.10.002.

Lyons, T.W., and Severmann, S., 2006, A critical look at iron paleoredox proxies: New insights from modern euxinic marine basins: Geochimica et Cosmochimica Acta, v. 70, p. 5698-5722, doi: 10.1016/j.gca.2006.08.021. 
1323

1324

1325

1326

1327

1328

1329

1330

1331

1332

1333

1334

1335

1336

1337

1338

1339

1340

1341

1342

1343

1344

1345

1346

1347

1348

1349

1350

1351

1352

1353

1354

1355

1356

1357

1358

1359

1360

1361

1362

1363

1364

1365

1366

1367

Martin, J.-M., and Meybeck, M., 1979, Elemental mass-balance of material carried by major world rivers: Marine Chemistry, v. 7. P. 173-206, doi:10.1016/03044203(79)90039-2.

März, C., Poulton, S.W., Beckmann, B., Küster, K., Wagner, T., and Kasten, S., 2008, Redox sensitivity of $\mathrm{P}$ cycling during marine black shale formation: Dynamics of sulfidic and anoxic, non-sulfidic bottom waters: Geochimica et Cosmochimica Acta, v. 72, p. 3703-3717, doi: 10.1016/j.gca.2008.04.025.

Mayer, T.D., and Jarrell, W.M., 2000, Phosphorus sorption during iron(III) oxidation in the presence of dissolved silica: Water Research, v. 34, p. 3949-3956, doi:10.1016/S0043-1354(00)00158-5.

Olivarez, A.M., and Owen, R.M., 1989, REE/Fe variations in hydrothermal sediments: Implications for the REE content of seawater: Geochimica et Cosmochimica Acta, v. 53, p. 757-762, doi:10.1016/0016-7037(89)90019-7.

Papineau, D., 2010, Global biogeochemical changes at both ends of the Proterozoic: Insights from phosphorites: Astrobiology, v. 10, p. 165-181, doi:10.1089/ast.2009.0360.

Peng, Shanchi, and Babcock, L.E., 2011, Continuing progress on chronostratigraphic subdivision of the Cambrian System: Bulletin of Geosciences, doi:

10.3140/bull.geosci.1273.

Planavsky, N.J., Rouxel, O.J., Bekker, A., Lalonde, S.V., Konhauser, K.O., Reinhard, C.T., and Lyons, T.W., 2010, The evolution of the marine phosphate reservoir: Nature, v. 467, p. 1088-1090, doi:10.1038/nature09485

Porter, S.M., 2004a, Halkieriids in Middle Cambrian phosphatic limestones from Australia: Journal of Paleontology, v. 78, p. 574-590, doi: 10.1666/0022-3360(2004) 078<0574:HIMCPL $>2.0 . C O ; 2$.

Porter, S.M., 2004b, Closing the phosphatization window: testing for the influence of taphonomic megabias on the pattern of small shelly fossil decline: Palaios, v. 19, p. 178183, doi: 10.1669/0883-1351(2004)019<0178.

Poulton, S.W., and Canfield, D.E., 2005, Development of a sequential extraction procedure for iron: implications for iron partitioning in continentally derived particulates: Chemical Geology, v. 214, p. 209-221, doi: 10.1016/j.chemgeo.2004.09.003.

Poulton, S.W., and Canfield, D. E., 2006, Co-diagenesis of iron and phosphorus in hydrothermal sediments from the southern East Pacific rise: implications for the evaluation of paleoseawater phosphate concentrations: Geochimica et Cosmochimica Acta, v. 70, p. 5883-5898, doi: 10.1016/j.gca.2006.01.031. 
1368 Poulton, S.W., and Canfield, D.E., 2011, Ferruginous Conditions: A Dominant Feature of 1369 the Ocean through Earth's History: Elements, v. 7, p. 107-112,

1370 doi:10.2113/gselements.7.2.107.

1371

1372

1373

Poulton S. W., and Raiswell R., 2002, The low-temperature geochemical cycle of iron:

1374

1375

1376

1377

1378

1379

1380

1381

1382

1383

1384

1385

1386

1387 from continental fluxes to marine sediment deposition: American Journal of Science, v. 302, p. 774-805, doi: 10.2475/ajs.302.9.774.

Poulton S. W., Fralick, P.W., and Canfield, D.E., 2004, The transition to a sulphidic ocean $\sim 1.84$ billion years ago: Nature, v. 431, p. 173-177, doi:10.1038/nature02912.

Raiswell, R., and Berner, R.A., 1987, Organic carbon losses during burial and thermal maturation of normal marine shales: Geology, v. 15, p. 853-856, doi: doi: 10.1130/00917613(1987)15<853:OCLDBA>2.0.CO;2.

1388

1389

1390

1391

1392

Raiswell, R., and Canfield, D.E., 1998, Sources of iron for pyrite formation in marine sediments: American Journal of Science, v. 298, p. 219-245, doi: 10.2475/ajs.298.3.219.

Raiswell, R., Newton, R.J., and Wignall, P.B., 2001, An indicator of water-column anoxia: resolution of biofacies variations in the Kimmeridge Clay (Upper Jurassic, U.K.): Journal of Sedimentary Research, v. 71, p. 286-294, doi: 10.1306/070300710286.

Randall, S.R., Sherman, D.M., and Vala Ragnarsdottir, K., 2001, Sorption of As(V) on green rust $(\mathrm{Fe} 4(\mathrm{II}) \mathrm{Fe} 2(\mathrm{III})(\mathrm{OH}) 12 \mathrm{SO} 4 \cdot 3 \mathrm{H} 2 \mathrm{O})$ and lepidocrocite $(\gamma-\mathrm{FeOOH})$ : Surface 1393 complexes from EXAFS spectroscopy: Geochimica et Cosmochimica Acta, v. 65, p. 1015-1023, doi:10.1016/S0016-7037(00)00593-7.

1394 Redfield, A.C., 1958, The biological control of chemical factors in the environment: 1395 American Scientist, v. 64, p. 205-221.

1396

Riggs, S.R., 1986, Proterozoic and Cambrian phosphorites - specialist studies:

1398 phosphogenesis and its relationship to exploration for Proterozoic and Cambrian

1399 phosphorites: in Cook, P.J., and Shergold, J.H., eds., Phosphate deposits of the word:

1400 1401 1402 1403 1404 1405 1406 1407 Proterozoic and Cambrian phosphorites, Volume 1: Cambridge, UK, Cambridge University Press, p. 352-368.

Ruttenberg, K.C., 1992, Development of a sequential extraction method for different forms of phosphorus in marine sediments: Limnology and Oceanography, v. 37, p. 14601482, doi: 10.4319/1o.1992.37.7.1460.

Ruttenberg, K.C., and Berner, R.A., 1993, Authigenic apatite formation and burial in sediments from non-upwelling, continental margin environments: Geochimica et

1408 1409 1410 1411 Cosmochimica Acta, v. 57, p. 991-1007.

1412

Saltzman, M.R., 2005, Phosphorus, nitrogen, and the redox evolution of the Paleozoic oceans: Geology v. 33, p. 573-576, doi: 10.1130/G21535.1. 
1413 Schrag, D.P., Higgins, J.A., Macdonald, F.A., and Johnston, D.T., 2013, Authigenic 1414 carbonate and the history of the global carbon cycle: Science, v. 339, p. 540-543, doi:

$141510.1126 /$ science.1229578.

1416

1417

1418

1419

1420

1421

1422

1423

1424

1425

1426

1427

1428

1429

1430

1431

1432

1433

1434

1435

1436

1437

1438

1439

1440

1441

1442

1443

1444

1445

1446

1447

1448

1449

1450

1451

1452

1453

1454

1455

1456

1457

1458
Schuffert, J.D., Jahnke, R.A., Kastner, M., Leather, J., Sturz, A., and Wing, M.R., 1994, Rates of formation of modern phosphorite off western Mexico: Geochimica et Cosmochimica Acta, v. 58, p. 5001-5010, doi: 10.1016/0016-7037(94)90227-5.

Schuffert, J.D., Kastner, M., and Jahnke, R.A., 1998, Carbon and phosphorus burial associated with modern phosphorite formation: Marine Geology, v. 146, p. 21-31.

Scranton, M.I., McIntyre, M., Astor, Y., Taylor, G.T., Mueller-Karger, F., and Fanning., K., 2006, Temporal variability in the nutrient chemistry of the Cariaco Basin: in: Neretin, L.N. (ed.), Past and Present Water Column Anoxia: Springer Berlin Heidelberg New York, p. 139-160.

Severmann, S., Lyons, T.W., Anbar, A., McManus, J., and Gordon, G., 2008, Modern iron isotope perspective on the benthic iron shuttle and the redox evolution of ancient oceans: Geology, v. 36, p. 487-490, doi: 10.1130/G24670A.1.

Severmann, S., McManus, J., Berelson, W.M., and Hammond, D.E., 2010, The continental shelf benthic iron flux and its isotopic composition: Geochimica et Cosmochimica Acta, v. 74, p. 3984-4004, doi: 10.1016/j.gca.2010.04.022.

Shaffer, G., 1986, Phosphate pumps and shuttles in the Black Sea: Nature, v. 321, p. 515517, doi: $10.1038 / 321515 \mathrm{a} 0$.

Shemesh, A., 1990, Crystallinity and diagenesis of sedimentary apatites: Geochimica et Cosmochimica Acta, v. 54, p. 2433-2438, doi: 10.1016/0016-7037(90)90230-I.

Shen, Y., Schidlowski, M., and Chu, X., 2000, Biogeochemical approach to understanding phosphogenic events of the terminal Proterozoic to Cambrian: Palaeogeography Palaeoclimatology Palaeoecology, v. 158, p. 99-108, doi: 10.1016/S0031-0182(00)00033-X.

Siever, R., 1992, The silica cycle in the Precambrian: Geochimica et Cosmochimica Acta, v. 56, p. 3265-3272, doi: 10.1016/0016-7037(92)90303-Z.

Slomp, C.P., Epping, E.H.G., Helder, W., and Van Raaphorst, W., 1996, A key role for iron-bound phosphorus in authigenic apatite formation in North Atlantic continental platform sediments: Journal of Marine Research, v. 54, p. 1179-1205, doi: $10.1357 / 0022240963213745$.

Slomp C. P., Thomson J., and De Lange G. J., 2004, Controls on phosphorus regeneration and burial during formation of eastern Mediterranean sapropels: Marine Geology, v. 203, p. 141-159, doi: 10.1016/S0025-3227(03)00335-9. 
Southgate, P.N., 1988, A model for the development of phosphatic and calcareous lithofacies in the Middle Cambrian Thorntonia Limestone, northeast Georgina Basin,

Southgate, P.N., and Shergold, J.H., 1991, Application of sequence stratigraphic concepts to Middle Cambrian phosphogenesis, Georgina Basin, Australia: Journal of Australian Geology and Geophysics, v. 12, p. 119-144.

Strickland, J.D.H., and Parsons, T.R., 1972, A Practical Handbook of Seawater Analysis: Fish Research Board of Canada.

Swanson-Hysell, N.L, Rose, C.V., Calmet, C.C., Halverson, G.P., Hurtgen, M.T., and Maloof, A.C., 2010, Cryogenian glaciation and the onset of carbon-isotope decoupling: Science, v. 328, 608-611, doi:10.1126/science.1184508.

Trappe, J., 2001, A nomenclature system for granular phosphate rocks according to depositional texture: Sedimentary Geology, v. 145, p. 135-150, doi: 10.1016/S00370738(01)00103-8.

1478 Trefry, J.H., and Metz, S., 1989, Role of hydrothermal precipitates in the geochemical cycling of vanadium: Nature, v. 342, p. 531-533, doi:10.1038/342531a0.

1480 Trocine, R.P., and Trefry, J.H., 1988, Distribution and chemistry of suspended particles 1481 from an active hydrothermal vent site on the Mid-Atlantic Ridge at $26^{\circ} \mathrm{N}$ : Earth and 1482 Planetary Science Letters, v. 88, p. 1-15, doi:10.1016/0012-821X(88)90041-6.

1483 Tyrrell, T., 1999, The relative influences of nitrogen and phosphorus on oceanic primary 1484 production: Nature v. 400, p.525-531, doi:10.1038/22941.

1485 Van Cappellen, P., and Ingall, E.D., 1996, Redox stabilization of the atmosphere and 1486 oceans by phosphorus-limited marine productivity: Science, v. 271, p. 493-496, doi:

Vine, J.D., and Tourtelot, E.B., 1970, Geochemistry of black shale deposits; a summary report: Economic Geology, v. 65 no. 3 p. 253-272, doi: 10.2113/gsecongeo.65.3.253.

Walter, M.R., Veevers, J.J., Calver, C.R., and Grey, K., 1995, Neoproterozoic stratigraphy of the Centralia Superbasin, Australia: Precambrian Research, v. 73, p. 173195, doi: 10.1016/0301.9268(94)00077-5.

Wang, X., Hu, W., Yao, S., Chen, Q., and Xie, X., 2011, Carbon and strontium isotopes and global correlation of Cambrian Series 2-Series 3 carbonate rocks in the Keping area of the northwestern Tarim Basin, NW China: Marine an Petroleum Geology, v. 28, p. 992-1002, doi:10.1016/j.marpetgeo.2011.01.006. 
1501 Xiao, S. H. and Knoll, A. H., 1999, Fossil preservation in the Neoproterozoic

1502 Doushantuo phosphorite Lagerstatte, South China: Lethaia, v. 32, p. 219 - 240, doi:10.

1503 1111/j.1502-3931.1999.tb00541.x

1504

Xiao, S.H., and Knoll, A.H., 2000, Phosphatized animal embryos from the

Neoproterozoic Doushantuo formation at Weng'an, Guizhou, south China: Journal of

Zegeye, A., Bonneville, S. Benning, L.G., Sturm, A., Fowle, D.A., Jones, C. Canfield,

1513 Geology, v. 40, p. 599-602, doi:10.1130/G32959.1.

1514 Zhu, M.-Y., Zhang, J.-M., Li, G.-X., and Yang, A.-H., 2004, Evolution of C isotopes in 1515 the Cambrian of China: implications for Cambrian subdivision and trilobite mass 1516 extinctions: Geobios, v. 37, p. 287-301, doi: 10.1016/j.geobios.2003.06.001. 


\section{Figure captions:}

1518 Figure 1: (A) Areal extent of the constituent basins of the Neoproterozoic Centralian

1519 Superbasin. The black dot marks the drill locality for core NTGS 99/1 in the southern

1520 Georgina Basin. (B) Chronostratigraphy and lithostratigraphic nomenclature for the

1521 Northern Territory outcroppings of Cambrian strata within the southern Georgina Basin

1522 (modified from Dunster et al., 2007). The symbol “(?)" reflects uncertainties in

1523 correlating regional Australian trilobite Zones with International Cambrian System

1524 designations.

1526 Figure 2: Lithofacies of the Thorntonia Limestone and Arthur Creek Formation in NTGS 1527 99/1. (A) Sandy dolostone of the lower Thorntonia Limestone, just above the contact 1528 with the underlying Paleoproterozoic granite basement ( 595.8 - 595.6 mcd). (B)

1529 General character of the mottled-to-stylonodular, dolomitic lower Thorntonia Limestone

1530 (584-580.5 mcd). (C) Characteristic meter to sub-meter scale lithologic alternations and

1531 color variation within limestone of the middle Thorntonia Limestone (577.7 - 571.4

1532 mcd). (1) Denotes black and dark gray calcimudstone; (2) denotes lighter gray

1533 calcimudstone, wackestone and packstone; and (3) denotes limestone grainstone. Note

1534 the general up-package coarsening and lightening, often without cyclic or predictable

1535 variation. (D) Bioclastic grainstone to mudstone transition from 570.15 - 570.05 mcd

1536 (middle Thorntonia Limestone; all limestone). (E) Appearance of the vuggy, bioclastic

1537 dolomitic grainstone of the upper Thorntonia Limestone (left) and the overlying basal

1538 'hot shale' of the lower Arthur Creek Formation (right). Contact at 554.7 mcd. (F) The

1539 laminated siliciclastic shale/siltstone and calcimudstone facies of the lower Arthur Creek

1540 Formation. (G) Light-gray early diagenetic nodule (calcimudstone) displacing dark-gray

1541 laminations within the lower Arthur Creek Formation at 532.8 - 532.65 mcd (arrows

1542 mark the exterior of the nodule). (H) General appearance of the interbedded siliciclastic

1543 mudstone/siltstone and calcimudstone (neomorphosed to microspar) facies of the lower

1544 Arthur Creek Formation above $\sim 430 \mathrm{mcd}$.

1546 Figure 3: Photomicrographs under plane-polarized light of authigenic apatite distribution

1547 within the middle Thorntonia Limestone. (A) A limestone packstone with apatite 
1548 replacement specifically targeting the interior of conical small shelly fossil elements at

$1549570.35 \mathrm{mcd}$. (B) Wholesale matrix and grain phosphatization at of a limestone at 575.17

1550 mcd. (C) Dispersed, allochthonous grains of authigenic apatite within a limestone at

$1551560.69 \mathrm{mcd}$ (see text for discussion of origin).

1552

1553 Figure 4: Lithology and stable isotope chemostratigraphy of the Thorntonia Limestone

1554 and lower Arthur Creek Formation within drill core NTGS 99/1. For all panels, data for

1555 the lower and middle/upper Thorntonia Limestone are plotted in open and solid blue

1556 circles, respectively, while data for the Arthur Creek Formation are plotted in solid red

1557 circles. (A) Generalized stratigraphic column depicting the lithology of the lower, middle,

1558 and upper Thorntonia Limestone and the lower Arthur Creek Formation. Lithologic

1559 abbreviations: Siliciclastics: slts $=$ siltstone; Carbonates: $\mathrm{mds}=$ mudstone; wks $=$

1560 wackestone; $\mathrm{pks}=$ packstone; grn = grainstone. Vertical axis reflects meters core depth

1561 from the surface. (B) Carbonate carbon isotopic composition (relative to V-PDB). (C)

1562 Carbonate oxygen isotopic composition (relative to V-PDB). (D) Total organic carbon

1563 isotopic composition (symbol size scaled to wt.\% total organic carbon (TOC)). (E) Cross-

1564 plot of carbonate carbon and carbonate oxygen isotopic composition. (F) Cross-plot of

1565 organic carbon and carbonate carbon isotopic composition.

1566

1567 Figure 5: Phosphorus and iron speciation geochemistry, molar C:P ratios, and

1568 correlations between $\mathrm{P}$ and other geochemical metrics within the Thorntonia Limestone

1569 and Arthur Creek Formation. (A) The weight percent of total phosphorus (filled green

1570 circles) and subtotal phosphorus (open green circles) for those samples whose $\mathrm{P}_{\mathrm{Fe}}$

1571 concentrations were not determined from P-speciation geochemistry. Weight percent total

$1572 \mathrm{Fe}$ (open red circles) from Fe-speciation geochemistry. Note the logarithmic scale to

1573 emphasize, in particular, the $\mathrm{P}$ content of the middle and upper Thorntonia Limestone.

1574 (B) The weight percents of operationally-defined phosphorus phases as determined by

1575 phosphorus-speciation geochemistry. Note the logarithmic scale. See text for discussion

1576 of the operationally-defined P phases. (C) The weight percents of iron phases as

1577 determined by iron-speciation geochemistry. Note the logarithmic scale. (D) The molar

1578 ratio of organic carbon to total phosphorus. Grey line intersects the axis at $\mathrm{C}: \mathrm{P}=106: 1$, 
the canonical Redfield ratio. (E) Correlation between the weight percent phosphorus

1580 within individual samples as determined from ICP-AES versus that determined by the

1581 sequential extraction method (see Methods section). Slope of linear regression $=1.1 ; \mathrm{R}^{2}=$

1582 0.88. (F) Correlation between the zirconium to aluminum ratio (ppm/\%) and the

1583 operationally-defined $\mathrm{P}_{\mathrm{xl}}$ phase (see text for discussion) determined from phosphorus

1584 speciation geochemistry. (G) Cross-plot of the weight percent of highly reactive iron

1585 species ( $\mathrm{Fe}_{\mathrm{HR}}$; oxides, magnetite, pyrite, and iron carbonates) determined from iron-

1586 speciation geochemistry versus the weight percent of total phosphorus determined from

1587 phosphorous-speciation geochemistry.

1589 Figure 6: Iron-speciation geochemistry. For all panels, data for the lower and 1590 middle/upper Thorntonia Limestone are plotted in open and solid blue circles, 1591 respectively, while data for the laminated facies and interbedded siliciclastic/carbonate 1592 mudstone facies of the Arthur Creek Formation are plotted in solid and open red circles, 1593 respectively. Data from the Arthur Creek 'hot shale' appear as solid red circles with a 1594 black outline. (A) A cross-plot of the weight percent total iron $\left(\mathrm{Fe}_{\mathrm{T}}\right)$ versus the weight 1595 percent iron within highly reactive phases ( $\mathrm{Fe}_{\mathrm{HR}}$; oxides, magnetite, pyrite, and iron 1596 carbonates). We plot slopes of 1 and 0.38 as a reference for comparing these carbonate 1597 data to previously published iron-speciation data, but we do not advocate interpreting 1598 carbonate data (blue circles) within the canonical siliciclastic framework. Slope of 1599 regressions (not plotted) reflect the percentage of the total iron residing in highly reactive 1600 phases (lower Thorntonia $=57 \%, \mathrm{R}^{2}: 0.53$; middle/upper Thorntonia $=89 \%, \mathrm{R}^{2}: 0.95$; 1601 laminated facies of the Arthur Creek $=53 \%, \mathrm{R}^{2}: 0.44$; interbedded siliciclastic shale / 1602 siltstone and carbonate mudstone facies of the Arthur Creek $=26 \%, \mathrm{R}^{2}: 0.90$ ). (B) A 1603 cross-plot of the weight percent highly reactive iron $\left(\mathrm{Fe}_{\mathrm{HR}}\right)$ versus the weight percent iron 1604 within pyrite $\left(\mathrm{Fe}_{\mathrm{py}}\right)$. We plot slopes of 1 and 0.8 for reference (see (a)). Slope of 1605 regressions (not plotted) reflect the percentage of the highly reactive iron residing within 1606 pyrite (lower Thorntonia $=17 \%, \mathrm{R}^{2}: 0.07$; middle/upper Thorntonia $=64 \%, \mathrm{R}^{2}: 0.95$; 1607 laminated facies of the Arthur Creek $=75 \%, \mathrm{R}^{2}: 0.95$; interbedded siliciclastic shale / 1608 siltstone and carbonate mudstone facies of the Arthur Creek $=30 \%, \mathrm{R}^{2}: 0.50$ ). We note 1609 that the linear regression for the 'hot shale' $\left(\mathrm{Fe}_{\mathrm{py}}=0.8 *\left(\mathrm{Fe}_{\mathrm{HR}}\right)-0.2\right)$ is the same for the 
1610 lower Arthur Creek laminated facies exclusive of the 'hot shale' data. (C) A cross-plot of 1611 the weight percent highly reactive iron $\left(\mathrm{Fe}_{\mathrm{HR}}\right)$ versus iron carbonate $\left(\mathrm{Fe}_{\text {carb }}\right)$. Slope of

1612 regressions (not plotted) reflect the percentage of the highly reactive iron residing within

1613 iron carbonate (lower Thorntonia $=82 \%, \mathrm{R}^{2}: 0.62$; middle/upper Thorntonia $=31 \%, \mathrm{R}^{2}$ :

16140.82 ; laminated facies of the Arthur Creek $=25 \%, \mathrm{R}^{2}: 0.68$; interbedded siliciclastic shale

1615 / siltstone and carbonate mudstone facies of the Arthur Creek $=52 \%, \mathrm{R}^{2}: 0.73$ ). We note

1616 that the linear regression for the 'hot shale' $\left(\mathrm{Fe}_{\text {carb }}=0.25 *\left(\mathrm{Fe}_{\mathrm{HR}}\right)+0.15\right)$ is similar for the

1617 lower Arthur Creek laminated facies exclusive of the 'hot shale' data $\left(\mathrm{Fe}_{\mathrm{carb}}=\right.$

$\left.16180.20 *\left(\mathrm{Fe}_{\mathrm{HR}}\right)+0.15\right)$.

1619

1620 Figure 7: Assessing the potential contribution of organic-bound and iron-bound 1621 phosphorus (P) to authigenic apatite precipitation. For the case of organic-bound $\mathrm{P}$ 1622 delivery (left), the dashed boxes depict the median estimated weight percent organic 1623 matter (wt.\% $\hat{C}_{\text {org }}^{*}$ ) necessary to account for the measured wt.\% sedimentary P based on 1624 equation (1) with a Redfield ratio of 106C:1P. Dark grey boxes represent the median 1625 wt.\% total organic carbon (TOC) measured within samples. Light gray boxes represent 1626 the corrected wt.\% $\hat{C}_{\text {org }}^{*}$ (see discussion leading to equation (9)). All values plotted to 1627 scale. Organic carbon delivery can account for all of the $\mathrm{P}$ within the Arthur Creek 1628 Formation. In contrast, the blank area within the dashed Thorntonia Limestone box 1629 represents the amount of $\hat{C}_{\text {org }}^{*}$ that would have to have been remineralized to account for 1630 the observed sedimentary P content if it were sourced by organic-bound P alone.

1631 For the case of iron-bound P delivery (right), the dashed boxes depict the median 1632 measured wt.\% $\mathrm{P}_{\mathrm{T}}$ within samples while the dark grey boxes represent the estimated 1633 delivery of iron-bound $\mathrm{P}\left(\hat{P}_{F e}^{*}\right)$ as determined from equation (13) assuming a partition 1634 coefficient for ferrihydrite and a seawater phosphate concentration of $5 \mu \mathrm{m}$ (see text for 1635 discussion). All values plotted to scale. In this regard, and under these assumptions, the 1636 Fe-P delivery shuttle can account for all of the P within the Arthur Creek Formation. In 1637 contrast, only by invoking $\mathrm{Fe}^{2+}$ loss from the sediment column and preferential capture of 1638 Fe-bound $\mathrm{P}$ within authigenic phases, could the Fe-P shuttle have contributed more 1639 substantially (> 10\%) to the phosphatic carbonate of the Thorntonia Limestone. 


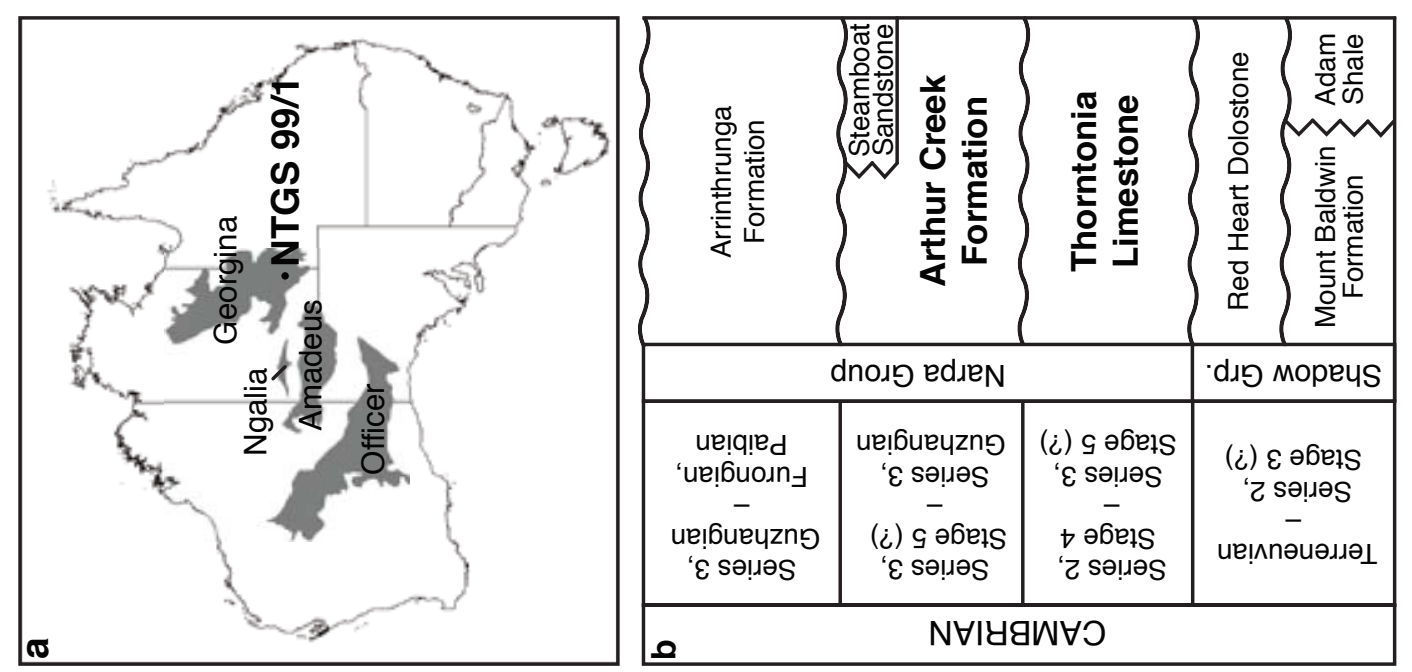

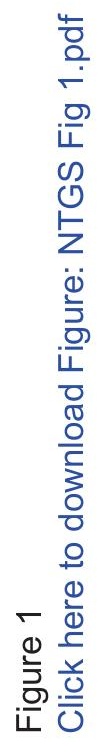




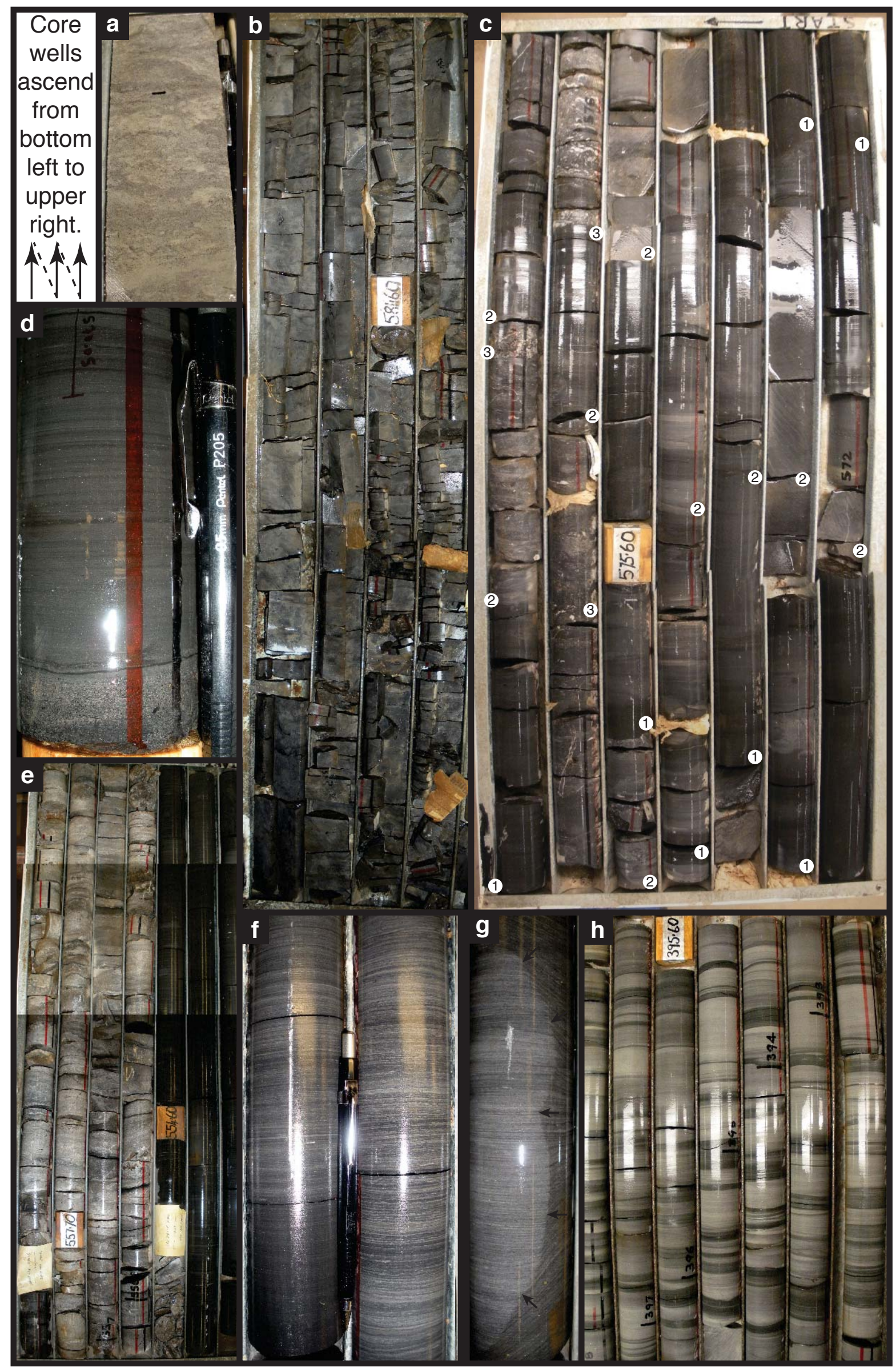


Figure 3

Click here to download Figure: NTGS Fig 3.pdf

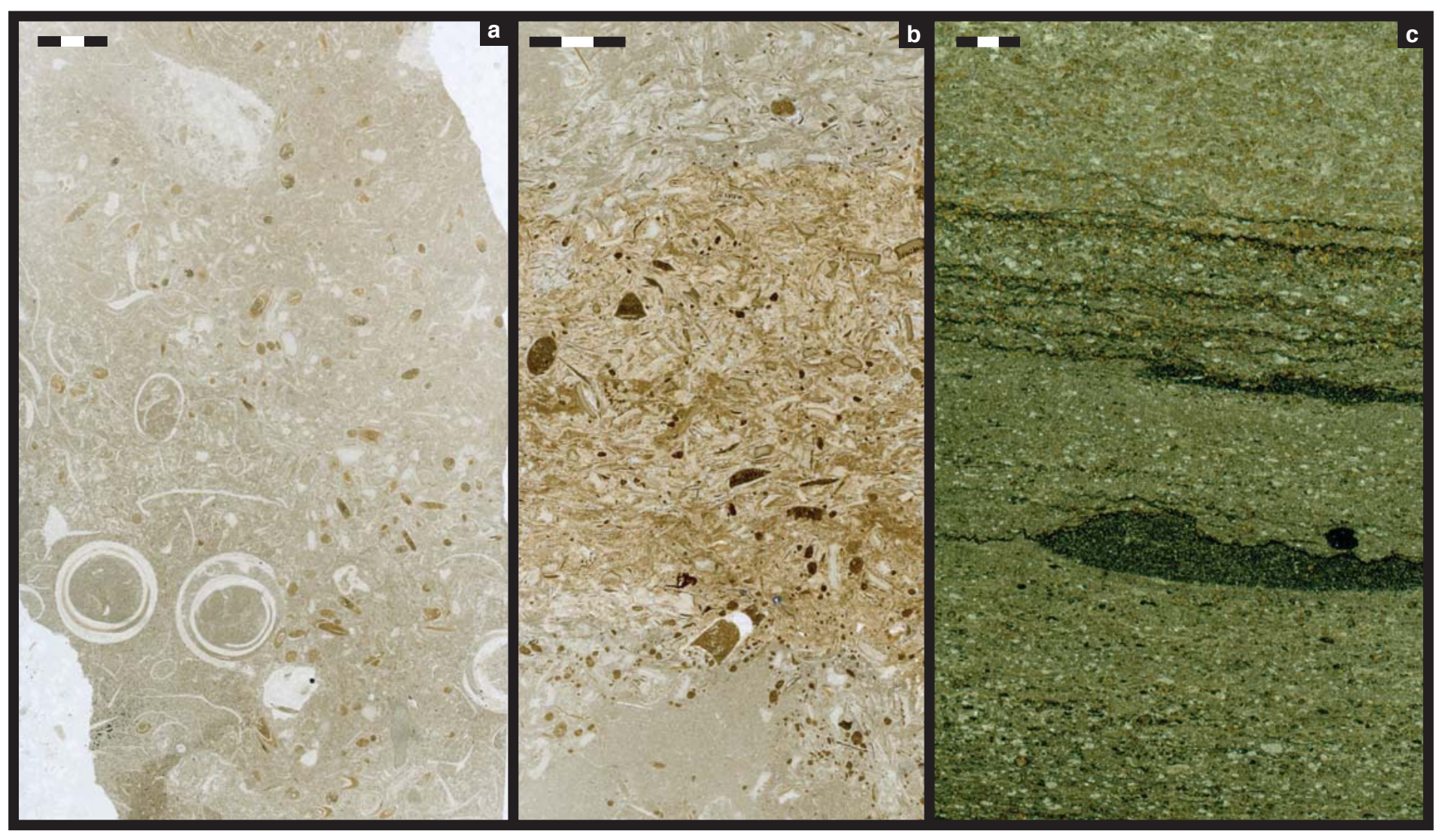



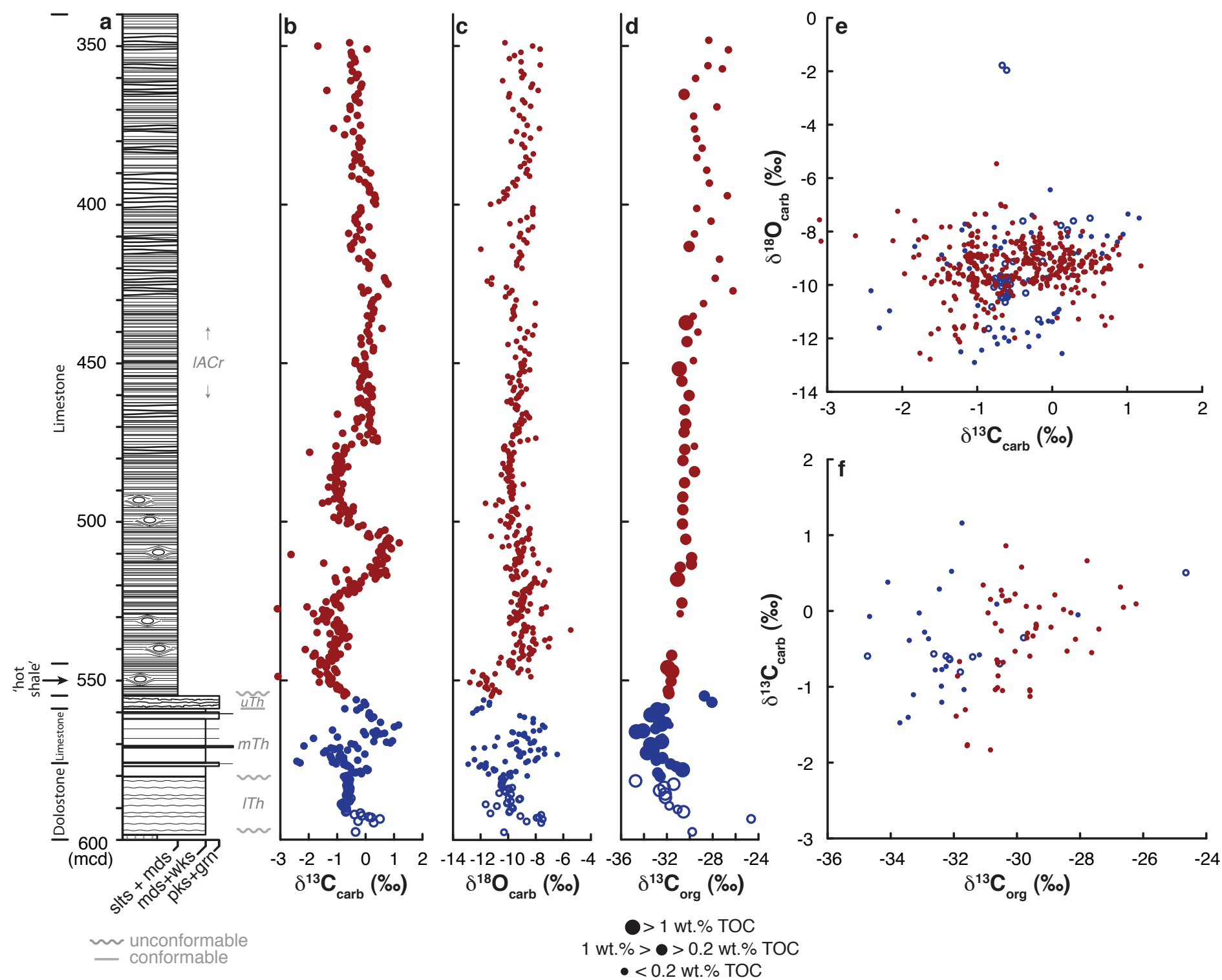

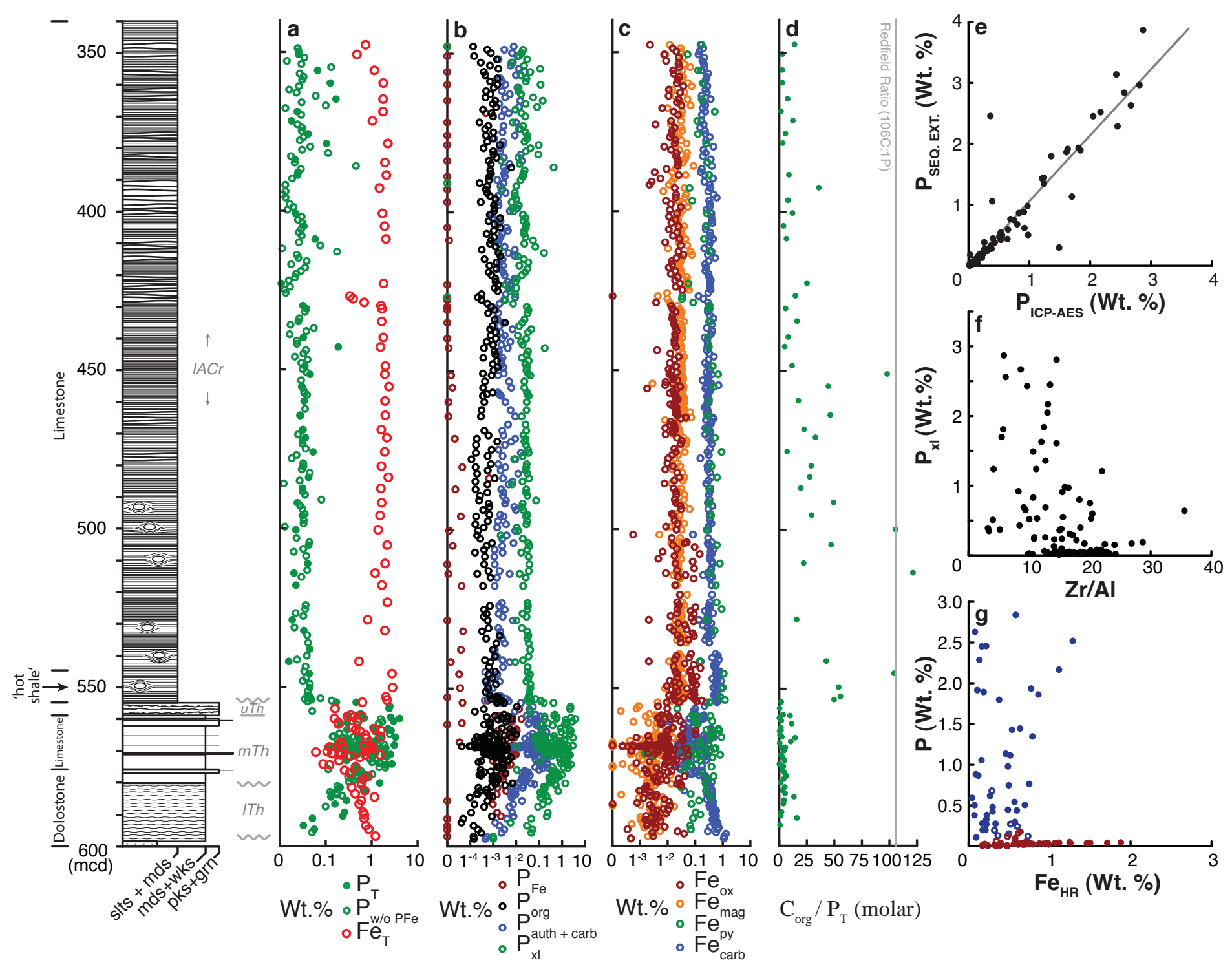

$\mathrm{C}_{\text {org }} / \mathrm{P}_{\mathrm{T}}$ (molar) 


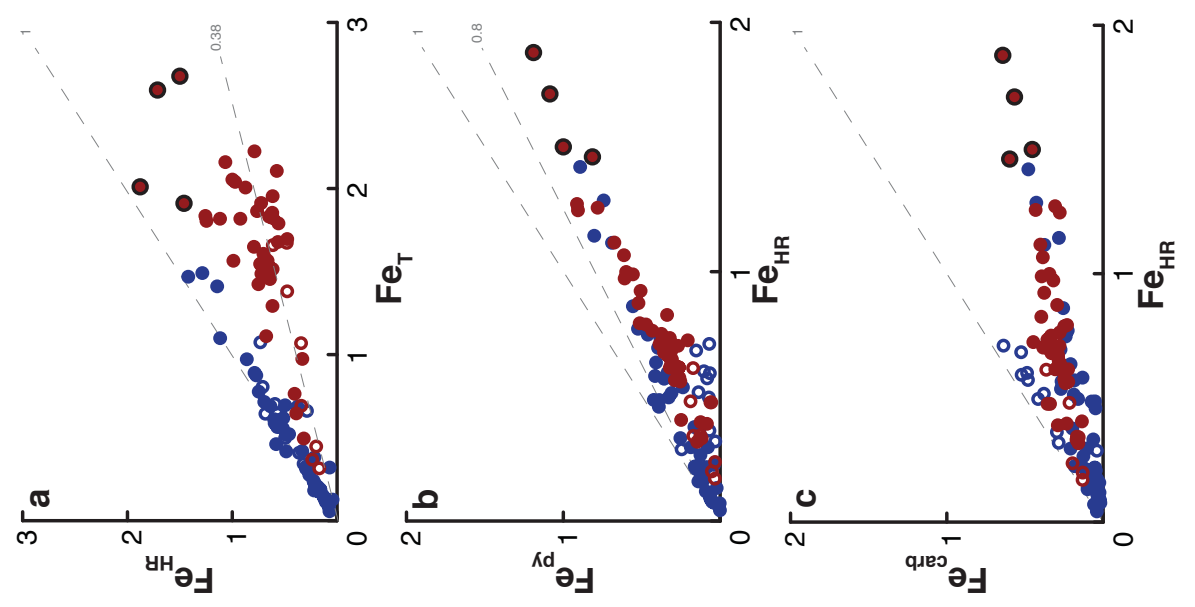

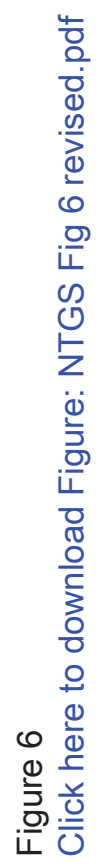



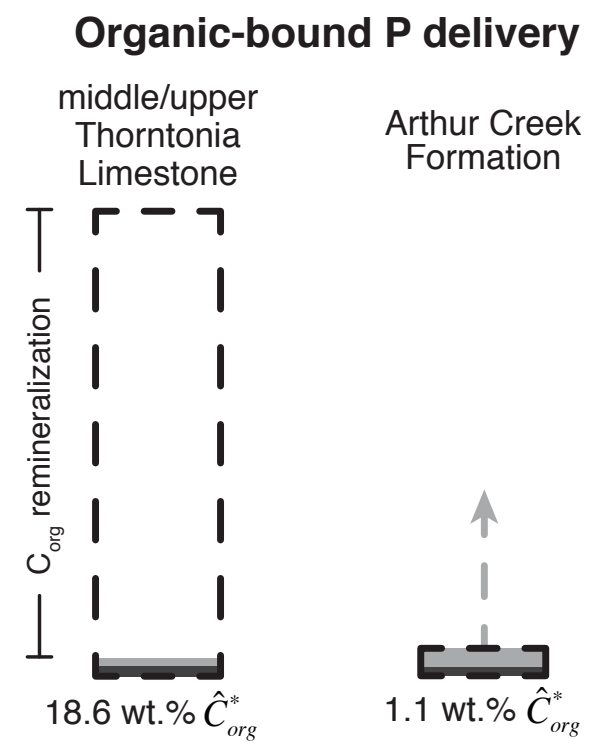

Iron-bound P delivery

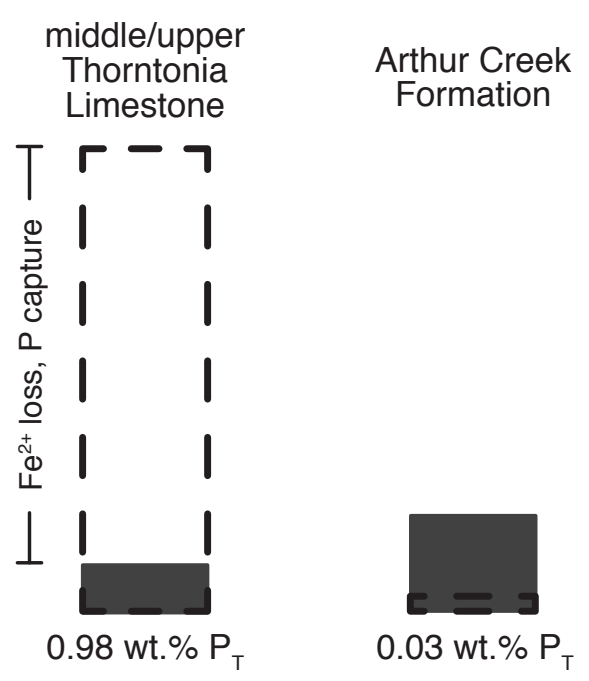


Click here to download Supplemental file: Supplementary Information for Revision 2.pdf

Supplementary Information
Click here to download Supp

(n) . (1) (1) (1) (1) (1) (1) . . . . . . . . . . . . 
Supplementary Figure 1
Click here to download Supplemental file: NTGS Fig S1.pdf

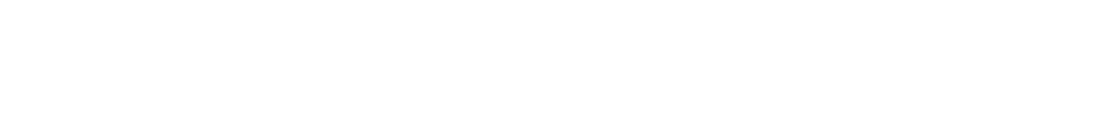
(1) 
Supplementary Figure 2
Click here to download Supplemental file: NTGS Fig S2.pdf

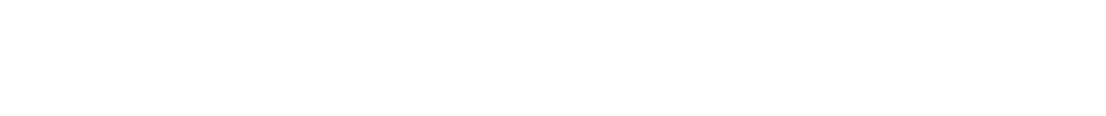

.

(1)

(1)

(1)

(1)

(1)

(1)

(1)

(1)

.

.

.

.

.

.

.

.

.

.

.

.

.

.

.

.

.

.

.

.

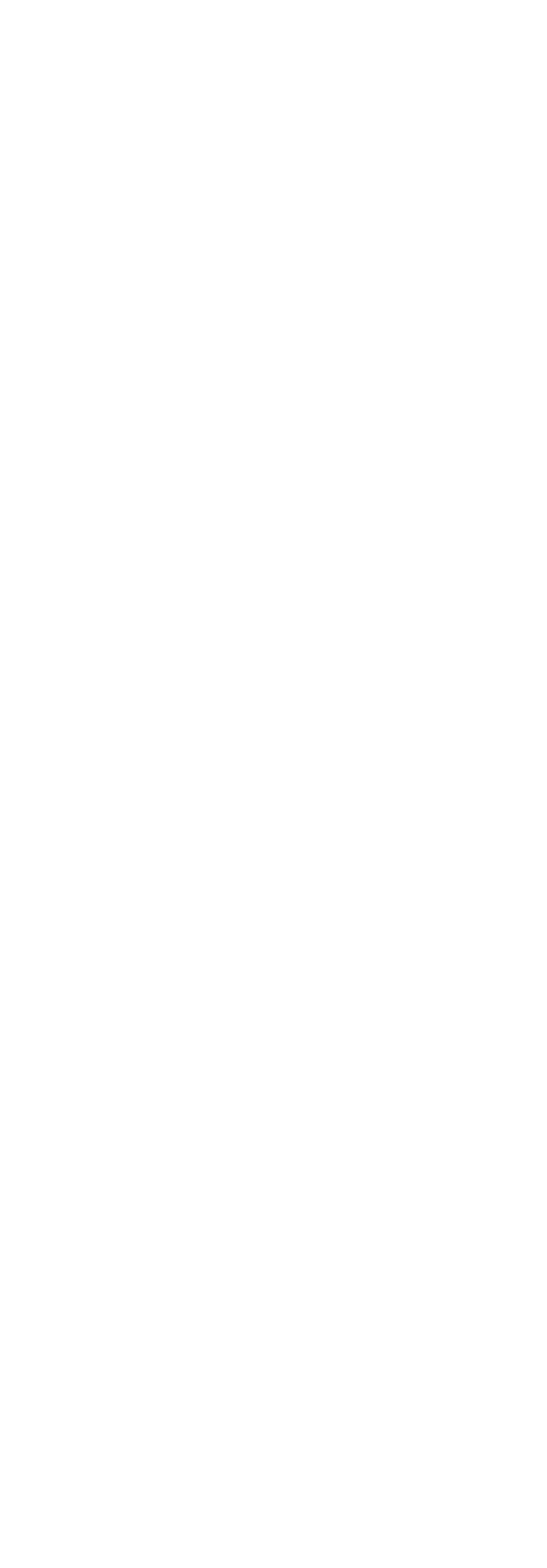


Supplementary Data Spreadsheet
Click here to download Supplemental file: NTGS Final Spreadsheet.xlsx

Supplementary Data Spreadsheet
Click here to download Supplemental file: NTGS Final Spreadsheet.xlsx

Supplementary Data Spreadsheet
Click here to download Supplemental file: NTGS Final Spreadsheet.xIsx

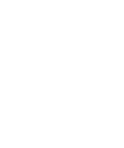

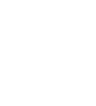

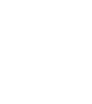

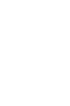
(1) (1)

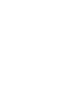
(1) (1)

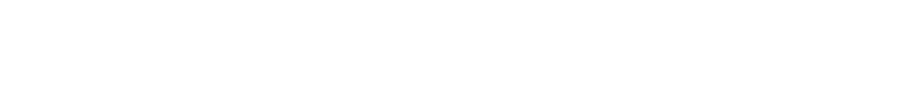

